\title{
Meso- and Cenozoic Tectonics of the Central Asian Mountain Belt: Effects of Lithospheric Plate Interaction and Mantle Plumes
}

\author{
N. L. Dobretsov, M. M. Buslov, \\ United Institute of Geology, Geophysics, and Mineralogy, Siberian Branch, Russian Academy of Sciences, \\ Novosibirsk-90, 630090, Russia \\ D. Delvaux, \\ Royal Museum for Central Africa, B-3080 Tervuren, Belgium \\ N. A. Berzin, AND V. D. Ermikov \\ United Institute of Geology, Geophysics, and Mineralogy, Siberian Branch, Russian Academy of Sciences, \\ Novosibirsk-90, 630090, Russia
}

\begin{abstract}
This paper reviews and integrates new results on: (1) the Late Paleozoic and Mesozoic evolution of Central Asia; (2) Cenozoic mountain building and intramontane basin formation in the Altay-Sayan area; (3) comparison of the tectonic evolutionary paths of the Altay, Baikal, and Tien Shan regions; (4) Cenozoic tectonics and mantle-plume magmatic activity; and (5) the geodynamics and tectonic evolution of Central Asia as a function of the India-Himalaya collision. It provides a new and more complete scenario for the formation of the Central Asian intracontinental mountain belt, compared with the generally accepted model of the "indentation" of the Indian plate into the Eurasian plate. The new model is based on the hypothesis of a complex interaction of lithospheric plates and mantle-plume magmatism. Compilation and comparison of new and published structural, geomorphological, paleomagnetic, isotopic, fission-track, and plume magmatism data from the Baikal area, the Altay, Mongolia, Tien Shan, Pamir, and Tibet show that the main stages of their orogenic evolution and basin sedimentation are closely related in time and space. After a long period of tectonic quiescence and peneplanation, Central and Southeast Asia were strongly affected by India-Eurasia collisional tectonics. During the first collisional stage (60 to $35 \mathrm{Ma}$ ), a first series of high mountains formed in the Himalayas, southern Tibet, and, possibly, the southern Tien Shan. Eocene deposits, younging northward, formed coevally with the orogeny in the near-Himalaya trough, Tarim, Tajik depression, and Fergana Basin. During post-collisional convergence, new depressions formed over wide territories, from the Tarim to Baikal and Altay areas. However, intensification of the deformation and uplift later were propagated northward, with development of the QinghaiTibetan Plateau (20 to $12 \mathrm{Ma}$ ), Tien Shan mountains (18 to $11 \mathrm{Ma}$ ), Junggar mountains and depression ( 8 to $5 \mathrm{Ma}$ ), and Altay, Baikal, and Transbaikal depressions and mountains ( $3 \mathrm{Ma}$ ).

Northward propagation of the deformation front from the Himalayan collision zone is suggested by regular northward younging of mountains and intramontane basins. Evidence of this includes: (1) India thrusting under Tibet, resulting in the rotation of the latter (60 to 35 $\mathrm{Ma})$; (2) subsidence of the Tarim ramp depression, the rise of the Tien Shan, and the migration of both the Tien Shan and Tarim to the northwest along the Junggar and Talas-Fergana strike-slip faults (35 to $8 \mathrm{Ma}$ ); (3) subsidence of the Junggar plate, counterclockwise rotation of the Mongolian and Amur plates ( 8 to $3 \mathrm{Ma}$ ); and (4) rise of the Altay, Hangai, and Transbaikal areas, clockwise rotation of the Amur plate, and rapid opening of the Baikal rift. There is a clear relation between tectonics (rotation of the Tibet and Amur microplates, displacement along plate boundaries) and plume magmatism. The effects of the latter on moving plates are deduced from migration of the Tien Shan volcanic area toward the Tibet area and of the South Mongolian volcanic migration toward the Hangai area. Magmatism and tectonic processes became synchronous just after India collided with the South Himalaya area (60 Ma) and the Pamirs ( $35 \mathrm{Ma})$. Plumes beneath the Asian plate are considered to be responsible for the rotation of the microplates and for the northward propagation of tectonic activity from the zone of collision. Mantle magmatism is lacking beneath the Altay. In this case, mountain-building processes and
\end{abstract}


basin-formation mechanisms likely are related to external sources of deformation originating from the India-Pamir convergence. In addition, they also may be related to the general translation and rotation of microplates.

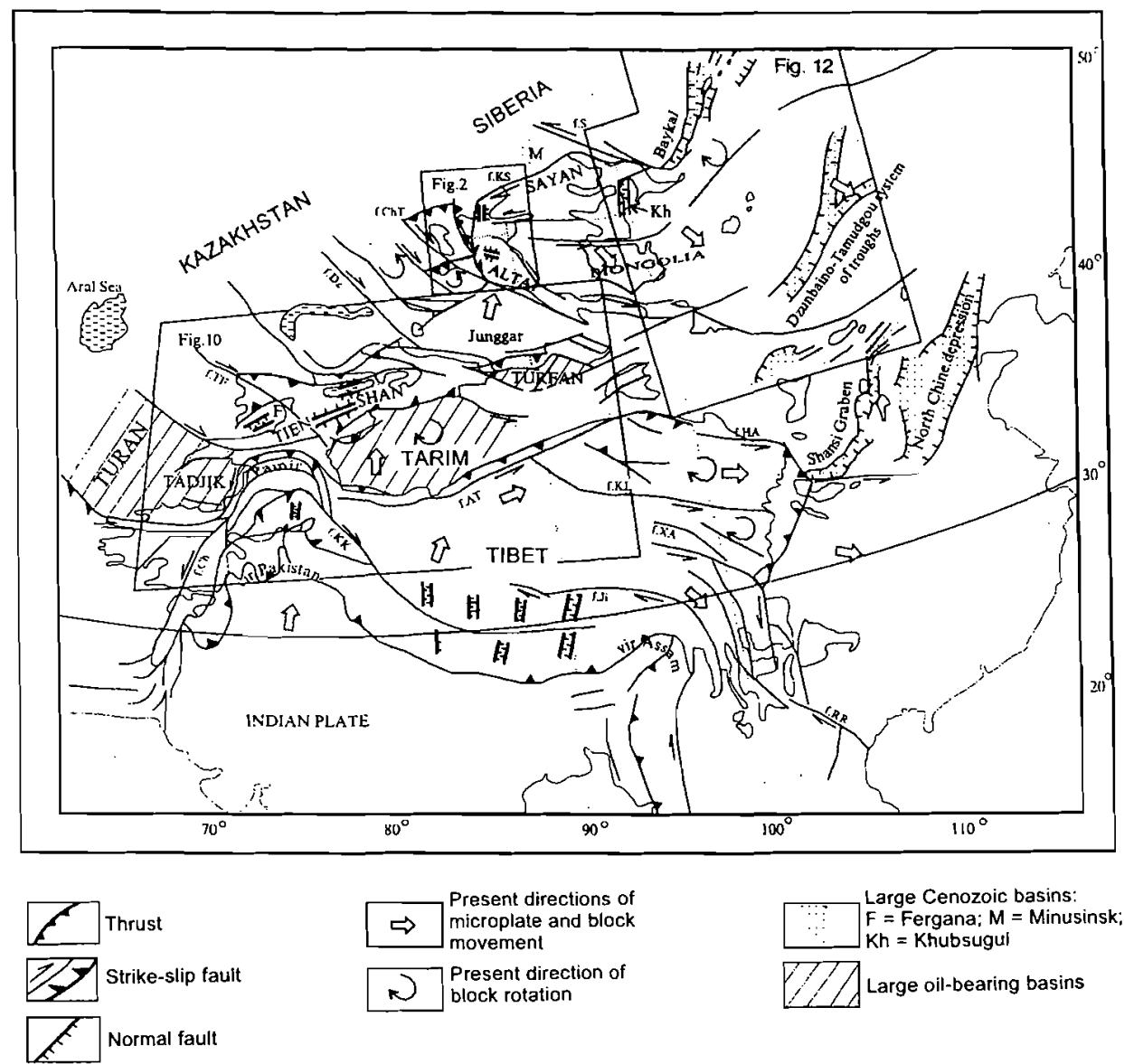

FIc. 1. Cenozoic tectonics in Asia (refined and modified after Cobbold and Davy, 1988). Dark areas represent mountains and uplifts over $2000 \mathrm{~m}$ in elevation. Large faults: AT = Altyn Tagh; Ch = Chaman; ChT = CharyshTerekta $;$ Dz = Junggar HA = Hainan; He = Herat; Ji = Jiali; KL = Kunlun; KK = Karakorum; KS = Kurai-Sayan; RR = Riviere Rouge $; \mathrm{TF}=$ Talas-Fergana $; \mathrm{X}_{\mathrm{a}}=\mathrm{X}$ anshuihe .

\section{Introduction}

The Central Asian mountain belt is the largest intracontinental belt in the world. It extends for more than $5000 \mathrm{~km}$ from the Tien Shan $\left(55^{\circ}\right.$ E. Long.) to the Stanovoy Range $\left(125^{\circ}\right.$ E. Long.), with alternating mountain ranges and tectonic depressions (Fig. 1) - the Tien Shan (with the Fergana, Issyk-Kul', and Yili basins), the Junggar-Saur (with Junggar and Zaysan basins), Altay and Sayan (with the Minusinsk and West Mongolian basins), the Baikal and Trans-Baikal regions (with the basins of the Baikal Rift Zone), and the Stanovoy
Range. The Himalayan orogenic belt, one to three thousand kilometers south of the Central Asian belt--including the Hindu Kush, Pamir, Karakorum, Himalaya, and southern Tibetdeveloped along the collisional boundary of the Indian plate. Between these two major belts, a series of large Mesozoic-Cenozoic oil-bearing depressions developed (the Turanian, Tajik, Tarim, and Turfan depressions) (Fig. 1).

Molnar and Tapponnier (1979) demonstrated that the India-Eurasia convergence provides a likely mechanism for explaining the Cenozoic tectonics of this broad area. The continental collision occurred generally between 60 and 35 
Ma (Patriat and Achache, 1984; Mercier et al., 1987; Le Pichon et al., 1992). At the initial collision, the area of the future Central Asian mountain belt was located 3000 to $5000 \mathrm{~km}$ from the plate boundary. At present, the Central Asian belt still is located some 1000 to 3000 $\mathrm{km}$ north of the initial plate boundary, the closest part being the southern Tien Shan and the Pamirs. After the initial collision, the northward motion of India continued at reduced velocity, causing a post-collisional indentation (of $\sim 2000 \mathrm{~km}$ ) of India into Eurasia (Tapponnier and Molnar, 1979; Cobbold and Davy, 1988; Davy and Cobbold, 1988).

The intracontinental setting of the Central Asian mountain belt provides a partial analogue to the Rocky Mountains (40 to $80 \mathrm{Ma}$ ) in the western United States (Gries, 1983). There, deformation also occurred within a continent far from a plate boundary. Seismic reflection profiles from the Rocky Mountains indicate that small crustal blocks were thrust atop the adjacent continental margin along moderately inclined $\left(30^{\circ}\right)$ thrust faults. This situation currently exists within the southern Tien Shan and Pamirs, unlike the more gently $\left(10\right.$ to $\left.15^{\circ}\right)$ dipping thrusts of the Himalaya. However, most of the Central Asian belt differs from the Rocky Mountain setting. Although the Pamirs, Himalaya, and southern Tibet appear to be similar to the Rocky Mountains, the northern and eastern Tibetan and adjacent Central Chinese rift systems resemble more closely the Basin and Range Province of the United States.

Many studies refer to data on the Tien Shan and Pamirs to support interpretations of intracontinental orogenic processes. The northern areas of the Central Asian mountain belt (Altay, Sayan, Baikal, Stanovoy), however, have not been involved in such interpretations, mostly because of the lack of English-language publications.

Molnar et al. (1994) outlined the following problems of intracontinental-belt dynamics:

(1) Why and how do intracontinental deformations propagate over broad areas, whereas subduction-zone deformations are concentrated along linear plate boundaries?

(2) Do zones of weakness already exist in the upper mantle or thinned crust, or are thermal anomalies responsible for the localization of the deformations?
(3) How does mantle flow generate intracontinental deformations and how does such flow relate to deformation observed in the upper crust?

(4) Do deformations result from instability within a thickened lithosphere beneath mountains, or could a threshold of stress be reached along the range margins?

In recent papers, a popular idea concerning the origin of the Central Asian mountain belt has been advanced, involving plate collision combined with a mantle-plume mechanism (Logachev and Zorin, 1992; Baljinnyam et al., 1993; Windley and Allen, 1993; Delvaux et al., in press). In the Altay region, evidence of Cenozoic mantle magmatic activity is lacking. Nevertheless, the main stages of Cenozoic Altay evolution resemble to a significant extent those in the Tien Shan and Baikal mountains (Delvaux et al., 1995a). However, the relationships between mantle-plume activity and the tectonic evolution of the Central Asian orogenic belt are more complicated than is commonly accepted.

In this paper, major attention will be devoted to the Mesozoic and Cenozoic evolution of the Altay massif compared with the other parts of the Central Asian orogenic belt, and to the links between collision tectonic phases and mantleplume activity. Recent data on the Altay tectonic evolution were obtained within the framework of the INTAS project on "Active Continental Tectonics and Evolution of Sedimentary Basins" in 1994-1995 (Dobretsov et al., 1995; Dobretsov and Klerkx, 1995; Delvaux et al., 1995b, 1995c, 1995d). For data on Central Asian mantle magmatism, the reader should consult our previous work (e.g., Dobretsov and Zagrusina, 1977; Bakirov and Dobretsov, 1978; Dobretsov and Ashchepkov, 1991).

In this paper, the following topics are addressed: (1) Late Paleozoic and Mesozoic evolution of the Central Asian belt, resulting in the formation of a highly heterogeneous basement, dissected by major strike-slip faults; (2) Cenozoic mountain building and intramontane basin (Kurai, Chuya, Teletskoye) formation in the Altay-Sayan area, controlled by reactivation of the Pre-Cenozoic fault system but without mantle plume activity; (3) comparison of the Cenozoic tectonic evolution of the Altay, Baikal, Tien Shan, and Pamir regions; (4) Cenozoic 
tectonics and mantle-plume magmatic activity; and (5) geodynamics and tectonic evolution of Central Asia and the India-Himalaya collisional zone.

\section{Late Paleozoic to Mesozoic Evolution of the Central Asian Belt}

During Permian time, the tectonic environment in Asia changed. The final collisional stage of the Paleoasiatic ocean resulted in the separation of three vast provinces-West Siberian, Central Asian, and Mongol-Okhotsk (+Paleotethys) (Berzin et al., 1994) - each with a different geodynamic environment. During the Paleozoic, however, the provinces shared a similar tectonic history.

In the Late Permian-Early Triassic, a rift system appeared within West Siberia, followed by the formation of an enormous marine oil-and-gas-bearing basin. In many studies (Aplonov, 1987; Zonenshain et al., 1990), this rift stage is considered to be a prolongation of the "Ob' ocean." Far to the south and southeast, in the Mongol-Okhotsk zone of PaleoTethys, oceanic basins developed in conjunction with subduction, collision, and deformation along the PaleoAsian continental margins, with deformation intensity decreasing toward the West Siberian province. At the same time, the Central Asian orogenic zone formed between the Siberian Platform and the MongolOkhotsk province. This belt consists of an $\mathrm{E}-\mathrm{W}$-trending zone in the west (including the Altay-Sayan area, Mongolian Altay, and central and eastern Kazakhstan) and an eastern zone (including East Mongolia and Transbaikalia), which experienced plume magmatism and was influenced by the active continental margin of the Pacific. The formation of Mesozoic structures occurred in four stages-(1) Late Permian-Early Triassic; (2) Late TriassicMiddle Jurassic; (3) Late Jurassic-Early Cretaceous, and (4) Late Cretaceous-Paleogene. Each stage induced unconformities and produced different volcanic-sedimentary molasses (Ermikov, 1994). These stages are described in greater detail below.

Stages in the formation of Mesozoic structures

During Triassic time, the western zone (Altay-Sayan area and Mongolian Altay) repre- sented a zone of elevations and erosion. In the eastern zone, alkaline granitic intrusions and post-collisional dikes are typical of this stage. By the Late Triassic, a peneplane with a thick weathering crust formed in the western zone, remnants of which are preserved or redeposited under coal-bearing Jurassic sediments (Bogolepov, 1967).

In the Early Jurassic, in the western zone, tectonic activity increased and intermontane and foremontane troughs developed in the Mongolian Altay (Fig. 2). Near the Altay, the intermontane basins partially inherited Triassic rift depressions. The foremontane troughs in Mongolia are bounded by the Hangai-Mongol Upland to the west and NW, and their fault pattern progressively disappears into the structures of the Altay and Western Sayan. During Jurassic time, basin formation was concentrated mainly along faults; along the extent of the Altay and the West Tuva faults, the PreAltay trough system (33-42 in Fig. 2) formed over a distance of $1200 \mathrm{~km}$ (Yanshin, 1975; Nagibina, 1981). To the southwest, the Mesozoic Mongolian Altay, several thousand meters in elevation, is bounded by the Hangai uplift; foremontane troughs along the latter are of rather low elevation.

In cross-section, the Mongolian Altay and the Pre-Altay trough system are asymmetric. The highest mountain level is reached at the northeastern margin, with the steep slopes dipping toward the troughs; deepest levels occur near the flanks of the mountain ridges.

Lower-Middle Jurassic deposits accumulated within narrow, linear fault-bounded troughs (nos. 28, 29, 36, and 41 in Fig. 2) and form a continental molasse 1 to $2 \mathrm{~km}$ thick dominated by coarse conglomerates and alluvial fanglomerates (Yanshin, 1975; Nagibina, 1981). Lacustrine and lacustrine-palustrine coal-bearing deposits are less important.

In addition to the rocks involved in Permian-Early Triassic rifting in Siberia, younger complexes, probably of Early or Middle Jurassic age, occur in zones of large faults initiated in the Paleozoic, suggesting that they were reactivated in the Mesozoic. In particular, EarlyMiddle Jurassic dike swarms of alkaline basalts were described in the southeastern Altay along the Charysh-Terekta and Kurai fault zones (Obolenskaya, 1983) and southwestern Tuva 


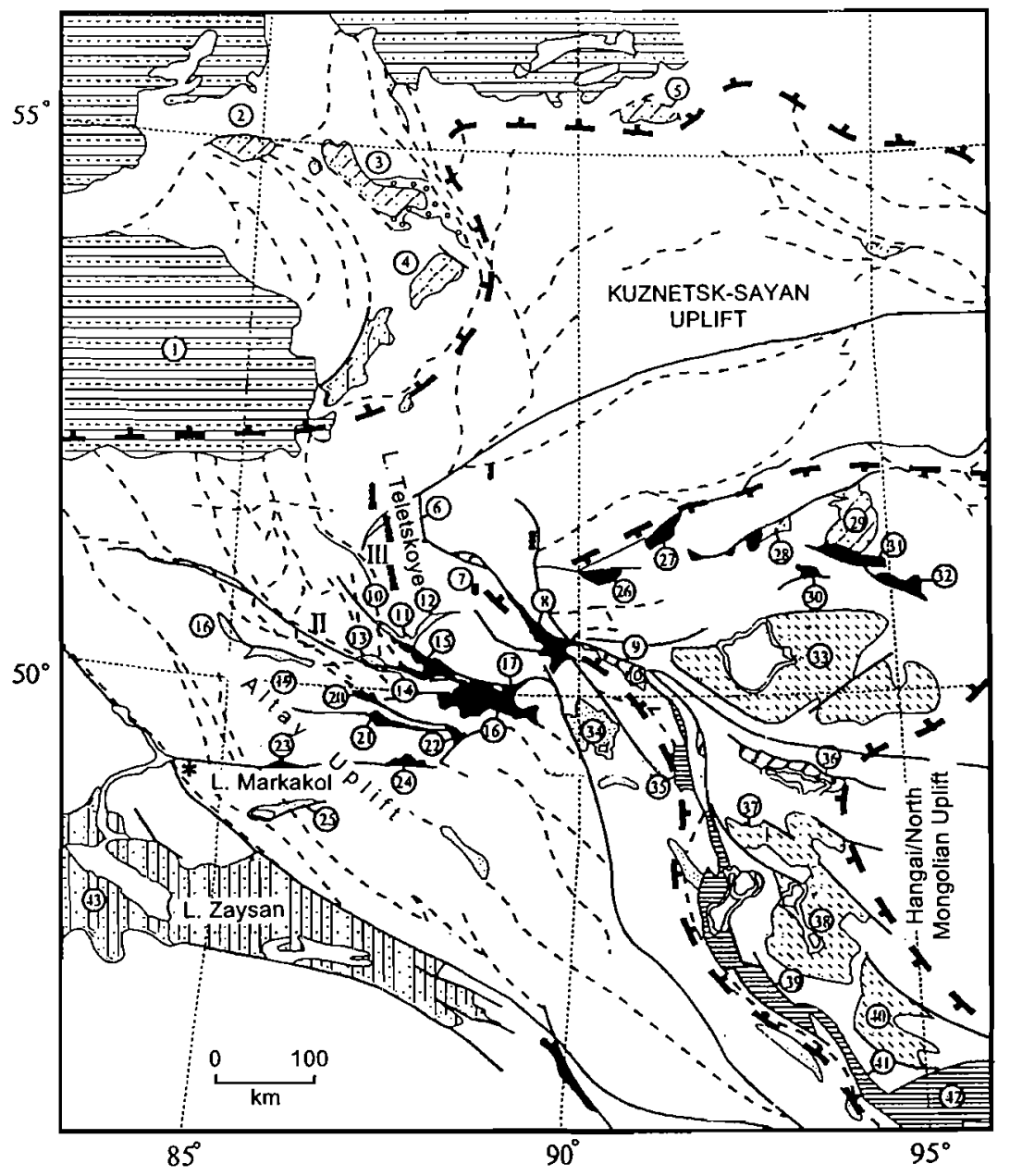

Deposits of grabens, basins, and troughs

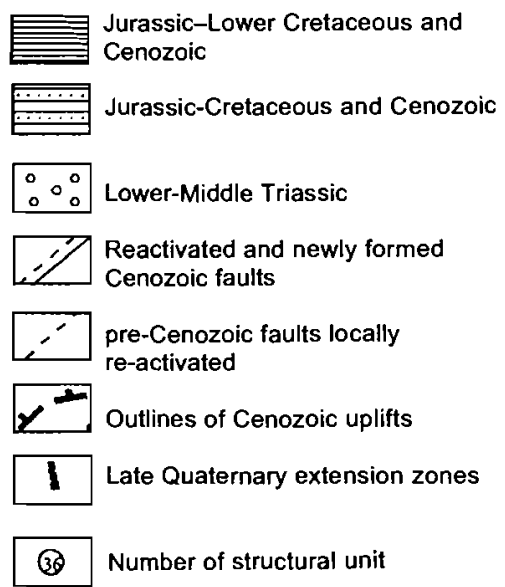

FIG. 2. Mesozoic and Cenozoic basins in the Altay-Sayan area and western Mongolia (Dobretsov et al., 1995). Legend: 1 = Biya-Barnaul; $2=$ Doronin; $3=$ Central; $4=$ Tutuyass; $5=$ Balakhtin; $6=$ Teletsk; $7=$ Saigonysh; $8=$ Dzhulunkul; $9=$ Kargin; 10 = Sarulukol; $11=$ Cheibekkol; $12=$ Ulagan; $13=$ Eshtykkol; $14=$ Kurai; $15=$ Aktash; $16=$ Chuya; 17 = Burgusun; $18=$ Abai; $19=$ Uimon; $20=$ Argut $; 21=$ Samakhin - Dzhasater $22=$ Tarkhatin; 23 = Chingistai; $24=$ Bertek; $25=$ Markakol; $26=$ Barlyk; $27=$ Sutkhol; $28=$ Inital; $29=$ Uluchkhem; $30=$ ElegestUngesh; $31=$ Baikhak; 32 = Chagyshai; $33=$ Ubsunur; $34=$ Achitnur; $35=$ Namiringol; $36=$ Khirgisnur; $37=$ Sangindalainur; $38=$ Kharanur; $39=$ Dzhereg; $40=$ Khoisuingobi; 41 = Ikhesnur; $42=$ Shargaingobi; $43=$ Zaysan . 
within the Kargin fault zone, which represents a southeastern extension of the Shapshal fault. Structurally, they continue the Jurassic troughs of the Pre-Altay trough system in Mongolia (faults II and III and depression no. 9 in Fig. 2).

The eastern zone is an area of magmatism of the Mongol-Okhotsk ocean's active margin. Early Mesozoic volcano-plutonic units consist of volcanics and alkaline granites and syenites in the west, and normal granodiorites and granites in the east. The volcanics are dated at 175 to $210 \mathrm{Ma}$, are dominated by dacite, orthofelsite, felsite, tuff, and lava breccia, and are overlain by Middle Jurassic deposits (Rublev et al., 1985).

In the Late Mesozoic (Late Jurassic-Early Cretaceous) the reactivation of fault zones and fissure eruptions, and the formation of faultrelated troughs, occurred in both the western and the eastern zones of the Central Asian belt. This stage is characterized by volcanic-free sedimentation in the western zone and by alkaline and subalkaline volcano-plutonic units in the eastern zone.

In the same period, in the western zone, wide, flat depressions formed along the western margin of the Hangai Mountains (nos. 33, 37-38, and 10 in Fig. 2). The most intense movements are recorded in the front of the Mongolian Altay, where $1700 \mathrm{~m}$ of Upper Jurassic coarseclastic proluvium accumulated (nos. 39, 41, and 42 in Fig. 2). The deposits appear to be more strongly dislocated there. Asymmetric folds with thrust faults dominate, with beds dipping at 45 to $60^{\circ}$ along the limbs and 70 to $80^{\circ}$ near the faults.

The Pre-Altay trough system (33-42 in Fig. 2 ), related to asymmetric uplift, generally resembles a large half-ramp structure resulting from horizontal compression combined with strike-slip displacements along the northeastern margin of the Mongolian Altay block. The strike-slip component is supported by strike-slip faults themselves and en echelon disposal of individual depressions and associated uplifts inside the Pre-Altay trough system. The half-ramp structure of individual depressions was noted by Nagibina (1981).

In the Gornyy Altay and West Sayan, Upper Mesozoic deposits are quite scarce. These are Jurassic continental sediments filling small half-grabens (e.g., Saigonysh-no. 7 in Fig. 2) or grabens (e.g., Kargin-no. 9 in Fig. 2) along the Shapshal fault zone (Basharina, 1975; Yanshin, 1975). Mesozoic dikes and small intrusive bodies also are abundant.

Movements continued along the faults during Early Cretaceous time. Deformed Lower Cretaceous deposits, unconformably overlain by Upper Cretaceous and Paleogene deposits, occur in southern Mongolia.

In the eastern zone (central and eastern Mongolia and Transbaikalia), the volcanic cover of Late Jurassic age can reach $2500 \mathrm{~m}$ in thickness. It consists of trachyandesite, trachybasalt, and basalt-andesite-rhyolite series and is overlain by $1500 \mathrm{~m}$ of coal-bearing molasse (Ermikov, 1994).

In the central Khingan Range the volcanics include coaliferous sequences 50 to $400 \mathrm{~m}$ thick (Nagibina, 1969). In southeastern and central Mongolia, this level consists of conglomerate, sandstone, shale, and gravelite intercalating with tuff, basalt, andesite, tuff sandstone, and tuff clays. The rocks are overlain by bituminous shale, siltstone, mudstone, and sandstonegravelite-clay.

The lithological facies of the Middle Jurassic-Lower Cretaceous sediments is highly variable, although some horizons are traced over large distances. For example, the upper coal-bearing molasse is found from Hangai to the Stanovoy Range, and the Barremian bituminous shale horizon occurs over the entire eastern part of the Central Asian belt.

Late Mesozoic intrusive rocks of the eastern zone are exposed in uplifts occurring chiefly as small diorite-granite or granodiorite-syenitegranite massifs. Only in the Stanovoy area are the massifs present as batholith-like and large fissure intrusions of granite, granodiorite, and diorite. Similiar to the situation in the Early Mesozoic analogues, there is a N-S compositional zonation. The central subzone, near the Stanovoy Range, is defined by granodiorite batholiths of the Udskaya series (normal alkalinity, high $\mathrm{Fe} / \mathrm{Mg}$ ratio in biotite, and $\mathrm{Na}_{2} \mathrm{O}$ and $\mathrm{K}_{2} \mathrm{O}$ contents of $\sim 6$ to $7 \%$ ). The western subzone is defined by diorite-monzonite intrusions with high-Mg biotite (Akatuyev and Shakhtamin massifs of the internal area), or by normal granite and Li-F granite (Kukulbei massif, Transbaikalia, and similar granites in the Malyy Khingan Range in the outer area). The age of magmatic rocks is 110 to $150 \mathrm{Ma}$. 


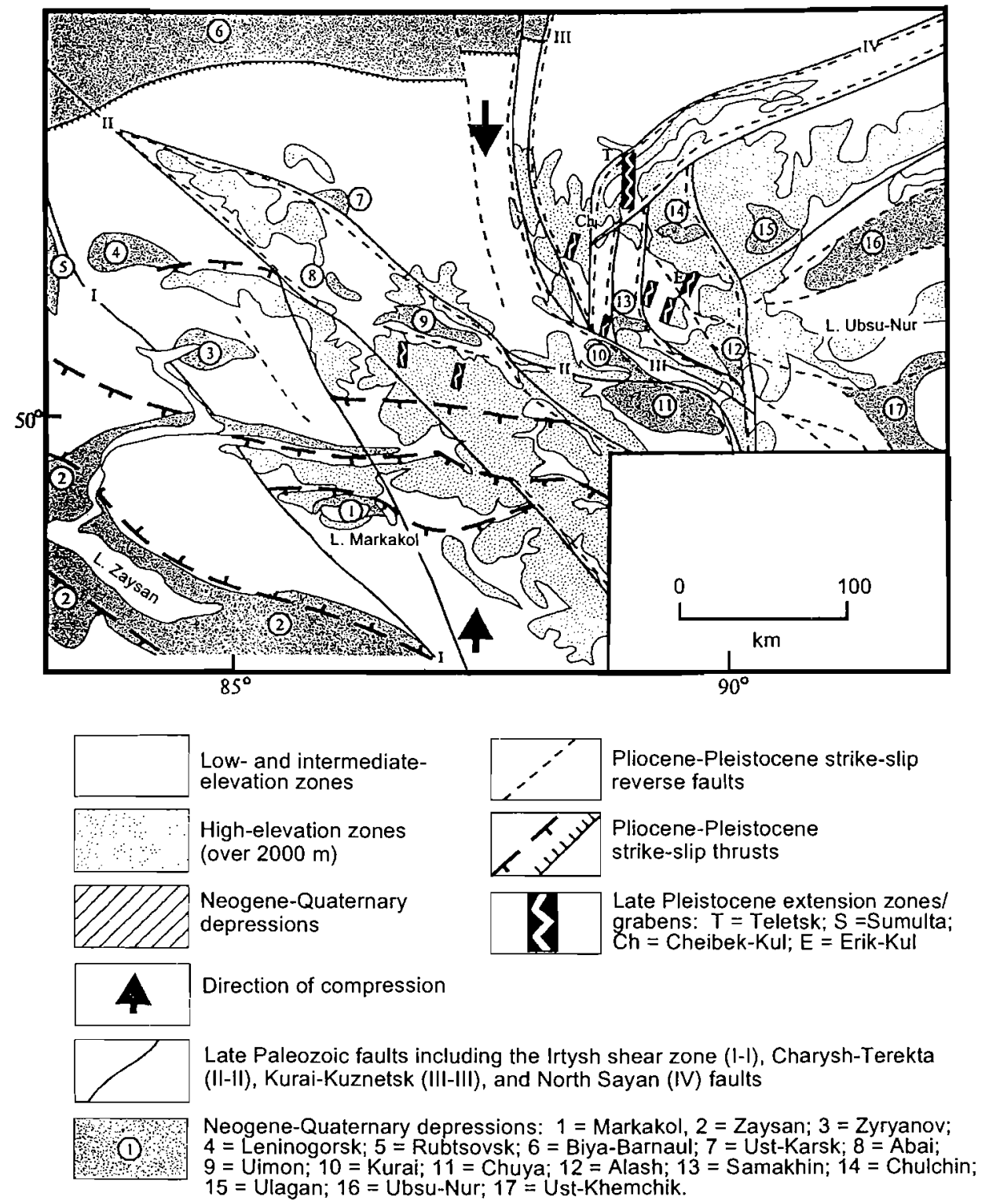

FIG. 3. Relationship between morphological and structural neotetonic elements and Late Paleozoic faults in the Altay-Sayan area and eastern Kazakhstan (Dobretsov et al., 1995).

By the Late Cretaceous, tectonism had ceased over the entire area. A platform environment was established during the Late Cretaceous-Early Paleogene; peneplanation and formation of a weathering crust are typical for this stage (Devyatkin, 1965, 1981; Yanshin, 1975). The thick, Late Cretaceous-Paleogene weathering crusts are preserved around the Zaysan and Biya-Barnaul depressions (Figs. 2 and 3). Inside the depressions themselves, clay sequences were deposited during Late CretaceousPaleogene time as a result of erosion of the weathering crusts and deposition in smooth depressions. Most investigators (Devyatkin, 1965, 1981; Yanshin, 1975) believe that intraAltay depressions were formed in the late Paleogene (from the early Oligocene to about $30 \mathrm{Ma}$ ), when an emerging arc differentiated into areas of uplift and troughs, with relative elevations reaching 300 to $700 \mathrm{~m}$ (Devyatkin, 1981).

\section{Fault kinematics in the Altay}

In the study of sedimentary basins, it is important to consider the environment, evolution, and kinematics of the largest faults that influence their evolution (Figs. 2 and 3). In the 
present structure of the Altay, the Late Paleozoic NW strike-slip faults and E-W thrusts and strike-slip faults dominate; N-S faults are subordinate. In the eastern Altay-Sayan area (West Sayan), many E-W and NE-striking faults appear.

In the Altay, especially in its southwestern Hercynian part, most of the NW strike-slip faults appear to have been active in the Late Carboniferous-Permian-e. g., the Irtysh shear zone (the largest strike-slip zone of the Altay) and adjacent zones (Ia and Ib in Fig. 3). There, Devonian and Lower Carboniferous rocks occur as thin tectonic lenses and sheets 100 to $300 \mathrm{~m}$ in width. The zone is intruded by Late Devonian to Late Permian gneissic gabbros and granitoids. K-Ar dating of biotite, K-feldspar, and whole rock indicates the Permian age of the final deformation and metamorphism -230 to $270 \mathrm{Ma}$ (Ponomarchuk et al., 1994) and 250 Ma after the recent unpublished Ar-Ar data of V. E. Ponomarchuk and A. S. Travin (pers. commun.).

Late Carboniferous-Permian age also is inferred for other NW strike-slip zones of the Altay; Devonian deposits of different facies are juxtaposed along the Charysh-Terekta fault, which, according to paleomagnetic data, initially were separated by $3000 \mathrm{~km}$ (Buslov and Kazanskiy, 1996). The thickness of blastomylonite and tectonic-zone and preliminary paleomagnetic data (unpublished material of M. Buslov, A. Kazanskiy, and Y. Fujiwara) show that displacements along the Irtysh shear zone are more than $1000 \mathrm{~km}$ (Sengör et al., 1993). These large-scale strike-slip displacements in the Late Paleozoic also are typical of other parts of the "Altaid" structure and, in terms of the model proposed by Sengör et al. $(1993,1994)$, they are explained by the fact that the Siberian and East European cratons approached and simultaneously rotated in a counterclockwise direction relative to one another.

The Mesozoic faults occur locally in a belt between the Hangai-Mongolian block and the Mongolian Altay. They follow inherited Paleozoic faults and accompany the Pre-Altay belt of Jurassic depressions. Remnants of smooth surfaces are preserved in many places and allow later movements to be estimated. Thus, the preCenozoic basement structure is controlled mainly by Late Paleozoic and Mesozoic strike- slip fault systems that were reactivated in Cenozoic time.

\section{Cenozoic Mountain Building and \\ Formation of Intermontane Basins in the Altay-Sayan Area}

After the Cretaceous-Early Paleogene period of tectonic stability and peneplanation, tectonic reactivation occurred in the Altay-Sayan area within three zones-(1) the Zaysan zone and its southeast continuation in Junggar; (2) the zone between Mongolian Altay and the Hangai-Mongolian uplift; and (3) the zone between the Hangai-North Mongolian and Kuznetsk-Sayan uplifts. These zones also were active earlier in the Mesozoic. Analysis of the occurrence of Mesozoic and Cenozoic complexes of the Altay-Sayan region, West Mongolia, and adjacent Chinese regions (Fig. 2) demonstrates that the Cenozoic structures inherited the pre-existing structural patterns in some cases, or appear to sharply transect them in other places.

The Cenozoic N-S compression and shear movements along pre-existing NW-trending faults led to the separation of the Altay and Kuznetsk-Sayan uplifts (Fig. 2). In the eastern Altay, the boundary between them runs nearly through the Shapshal fault zone, and in Mongolia, through the Tsagan-Shibetin zone. The movement of these blocks northward and northwestward was impeded by structures of the southern folded margin of West Siberia, which resulted in a wide band of ENE-oriented Cenozoic deformations crossing the entire Altay and continuing into the Tuva Basin, where it inherited the Mesozoic zones of deformation (Fig. 3).

In the Altay, the most strongly contrasting Cenozoic movements and deformations began near the boundary with Mongolia, where the Chuya, Kurai, Tarkhat, Bertek, Dzhulukul, and a number of smaller depressions formed. Their formation was favored by reverse or strike-slip movements along active pre-Cenozoic faults (Charysh-Terekta, Kurai, Shapshal) as well as along newly formed faults crossing the ancient structures (Fig. 3). A typical example of the latter is an E-W zone extending from the Naryn River valley to the upper reaches of the Bukhtarma and Akalakha River near the border 
with China and Mongolia. A chain of Cenozoic depressions (Naryn, Chingistai, Bertek) bounded by high ridges on the south runs along this zone.

In the Pleistocene, these deformations propagated toward northern regions of the Altay, where they were expressed as small near-fault troughs or E-W-trending tectonic scarps against the background of the CretaceousPaleogene peneplain (Novikov et al., 1995). The movements became less contrasting north ward. Gentle arch-like structures resembling restricted domes (Fig. 3) formed to the north and northwest of the Altay, at the border with the West Siberian and Biya-Barnaul depression. An $\mathrm{E}-\mathrm{W}$ reverse fault zone, however, is established there too, and Paleozoic formations were upthrown through it over OligoceneQuaternary deposits, with an amplitude of up to $700 \mathrm{~m}$ (Zyat'kova, 1977), of the Biya-Barnaul depression.

In the Cenozoic, microplates and large lithospheric blocks were separated in the northern regions of Central Asia. As a rule, they were bounded by pre-Cenozoic faults, chiefly playing the role of strike-slip faults in the Late Paleozoic. Irregular migration of these blocks, their relative displacement and thrusting, etc., not only led to their elevation to various hypsometric levels, producing orogenic systems, but also produced a deformation that culminated in the late Pliocene-early Pleistocene. In the Gornyy Altay, this is most apparent in the evolution of the Kurai-Chuya and Teletskoye depressions.

Thus, the territory of the Gornyy Altay is a highly elevated area where strike-slip faults, oblique thrusts, thrusts, and normal faults are combined. On the basis of the geometry of faults and earthquake focal mechanisms it was concluded that the maximal horizontal stress direction in the Altay was nearly N-S (Molnar and Tapponnier, 1975; Cobbold and Davy, 1988). A strike-slip regime with horizontal major maximum and minimum stress axes dominated. This conclusion accords with the main trajectories of movement of microplates and plates in Eurasia (Fig. 1).

Analyses of earthquake focal mechanisms (Zhalkovskiy et al., 1995) and stress-tension inversion (Delvaux et al., in press) suggests two zones in the Altay-Sayan area differing in terms of the orientation of the main stress axes in the earth's crust. The border separating them runs along the southwestern border of the Mongolian microplate (Fig. 1). In the vicinity of this border, in the Sayans, southern Tuva, and northern Mongolia, NNE-directed near-horizontal compression dominates. To the west, in the Altay, largely NNW-directed horizontal compression of the earth's crust is currently taking place.

The development of the Cenozoic structure of the Altay resulted in the variable morphology of the troughs and their separating ridges. With the area subdivided into small blocks continuing the movement of the troughs, the latter's geodynamic setting could change over time (see examples below). In some periods of neotectonic history, troughs formed as compression structures (ramps or half-ramps), and in others as structures without shear extension (grabens, "pull-apart" structures) or as shear zones without marked expression in relief (Delvaux et al., 1995c). By interacting with one another, some blocks appear to have rotated as well. Support for this rotation comes from the data obtained by tentative paleomagnetic study of the Neogene-Quaternary deposits of the Chuya Depression (Markov, 1977; Zykin and Kazansky, 1995; Thomas et al., 1996). Three typical examplesthe Kurai, Chuya, and Teletskoye will be discussed in detail (Figs. 4-7).

Tectonic and geomorphologic studies of the Kurai and Chuya Cenozoic depressions in Gornyy Altay (Delvaux et al., 1995c; Novikov et al., 1995; Zykin and Kazansky, 1995) indicate that they resulted from the complex interaction of tectonic, sedimentary, and climatic processes. Their structure is controlled by reactivation of Late Paleozoic faults. Climate changed from subtropical in the early Paleogene (pre-Eocene weathering surface) to glacial in the Pliocene (glacial deposits and erosion processes). The timing of tectonic movements and the orientation of the present strain field are correlated with tectonic movements induced by the IndiaEurasia collision. Major Cenozoic tectonic activity occurred in the late Oligocene-early Miocene and in the late Pliocene.

The geodynamic setting is dominated by a N-S to NNW-SSE horizontal compression. The Kurai and Chuya depressions developed at a high angle to the direction of the main horizontal compression. The depressions formed as a single "pull-apart" trough in the Oligocene and 


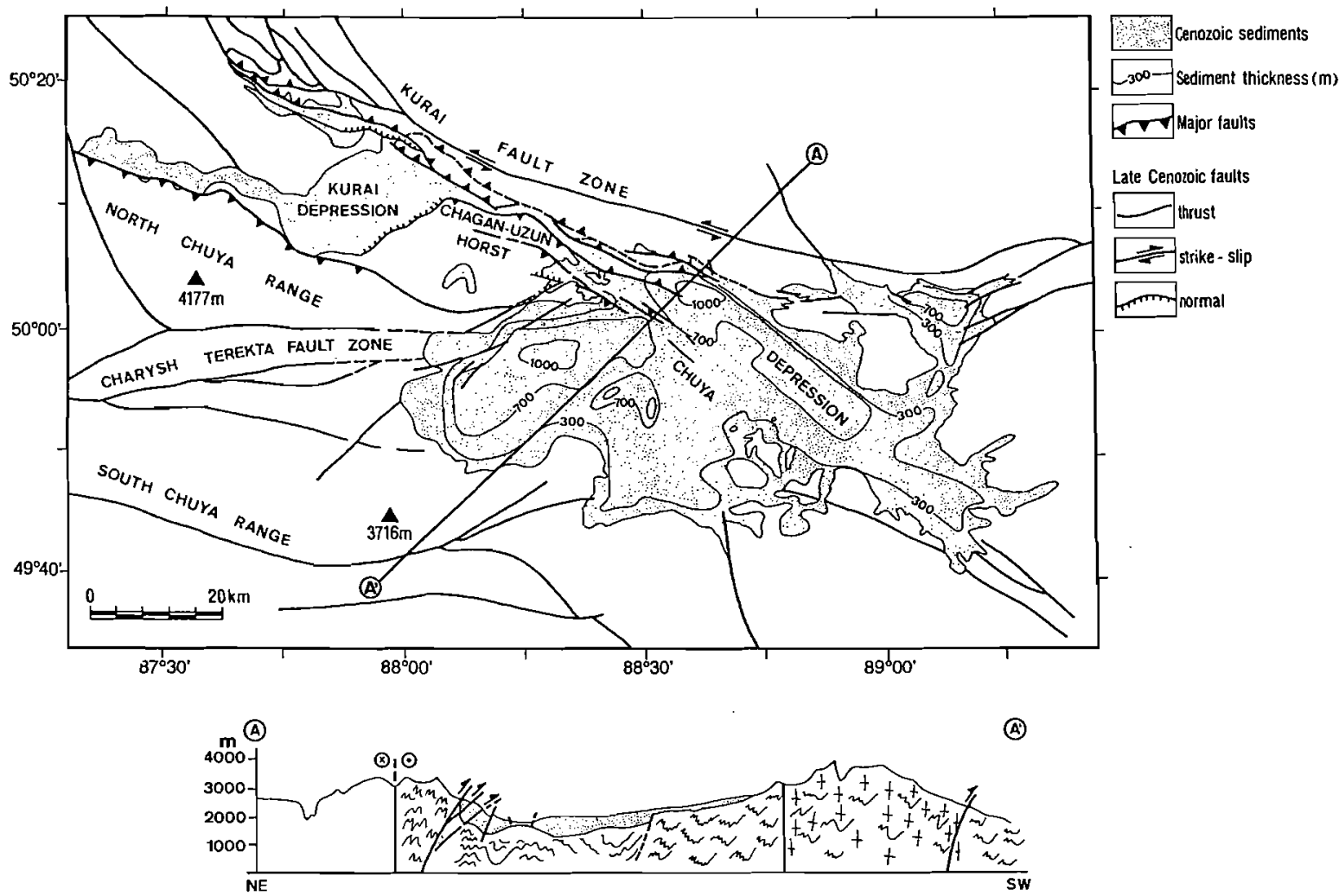

Fig. 4. Geological scheme and cross-section in Cenozoic deposits of the Chuya depression (after Buslov et al., 1996).

evolved as isolated ramp-type troughs in the Pliocene-early Pleistocene.

N-S-striking Lake Teletskoye (40 km long, 4 to $5 \mathrm{~km}$ wide, and $320 \mathrm{~m}$ deep) opened as a giant extension fracture at the margin of the Mongolian plate. It resulted from the reactivation of the sinistral West Sayan fault, and formed only in the early-middle Pleistocene (Fig. 6).

The present structure and kinematics of the Chuya-Kurai depression differ from those in the Tertiary (Fig. 4). The structure of the Tertiary depression was deduced based on the field study of Cenozoic sediments, gravimetry, and drilling data. The latter indicate the occurrence of a quite narrow graben filled by Tertiary deposits over $1000 \mathrm{~m}$ thick within the axial zone of the Chuya depression. The graben is bounded by an early Pleistocene oblique thrust from the north and early Pliocene strike-slip thrusts from the south (Fig. 4).

The Kurai and Chuya depressions are divided by the Chagan-Uzun massif, which occurs as an oblique rhomb-like horst 2600 to $2900 \mathrm{~m}$ in elevation. Within the massif, there are relics of
Tertiary deposits that were uplifted relative to the present bottom of the depressions. This provides evidence that the Kurai and Chuya depressions may have existed as a single basin during the Tertiary.

At the foot of Kurai Ridge, a Cenozoic stratigraphic succession of the Chuya depression is most completely presented (Fig. 5) as the Karakum $\left(\mathrm{Pg}_{3}{ }^{2-3}\right)$, Kochagach $\left(\mathrm{Pg}_{3}-\mathrm{N}_{1} \mathrm{l}-2\right)$, Tueryk $\left(\mathrm{N}_{1}{ }^{2-3}\right)$, Kyzylgir $\left(\mathrm{N}_{1}{ }^{3}-\mathrm{N}_{2}{ }^{1}\right)$, Beken $\left(\mathrm{N}_{2}{ }^{1}\right)$, Terek $\left(\mathrm{N}_{2}{ }^{2}\right)$, and Bashkauss $\left(Q_{1}\right)$ suites (Zykin and Kazansky, 1995). Through a basal horizon of conglomerates and gravelites, the Karakum suite overlaps Paleozoic rocks of Kurai Ridge. The Karakum suite is a continental molasse that marks the initial stage of the late Oligocene-early Miocene orogeny and the beginning of the intermontane Chuya depression. The Kochagach coaliferous sediments were deposited during a pre-Pliocene tectonic stabilization in a shallow-water lacustrine depression. The water depth gradually increased in the early Pliocene, with the deposition of marls and carbonates of the Tueryk suite in a large lacustrine depression. The size of the 


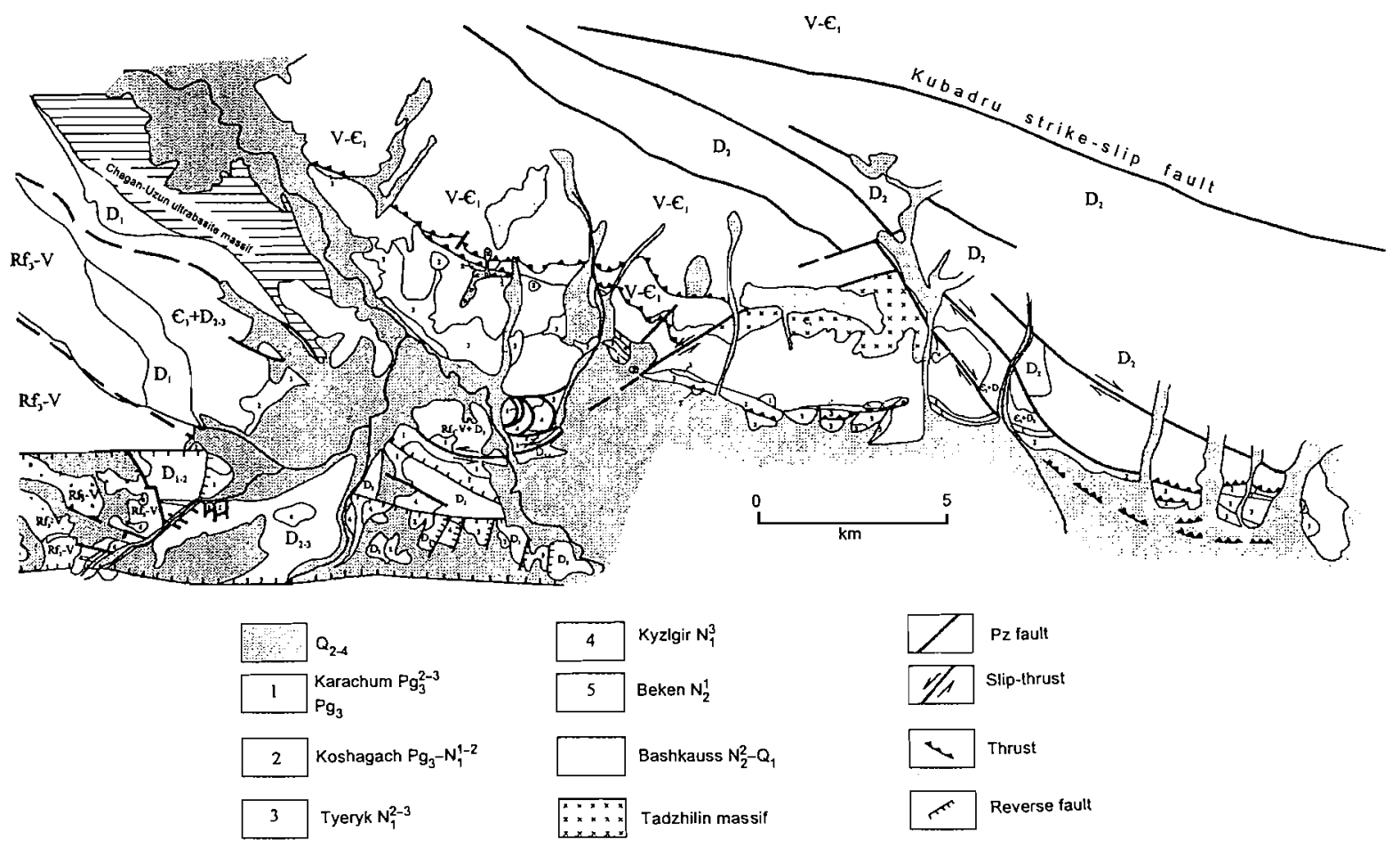

FIG. 5. Geological scheme of the western and northern parts of the Chuya depression (after Buslov et al., 1996).

latter exceeded that of the present depression. Relics of lacustrine deposits are found in the Chagan-Uzun massif, western Mongolia, and the Dzheltuluk depression. Sediments of the Kyzylgir suite accumulated within a large, longlived lacustrine basin under a stable tectonic regime. This is suggested by marly clays, stromatolitic limestone beds, and a fresh-water fauna with a high endemic level close to that of Lake Baikal (Zykin and Kazansky, 1995). The next tectonic stage began in the late Pliocene. It caused rapid uplift of Kurai Ridge and lake infilling with coarse-clastic rocks of the Beken suite. In the early Pleistocene, Kurai Ridge was thrust over the sediments of the Chuya depression. Accumulation of the Bashkauss suite of poorly sorted and poor-rounded rocks reflects the period of maximal growth of Kurai Ridge.

In the western Chuya depression, at the border with the Chagan-Uzun massif, sedimentation and neotectonics evolved differently. There are interruptions in sedimentation, as well as strike-slip, reverse-fault, and normalfault deformations of Oligocene, Miocene, and Holocene ages (Figs. 4 and 5 ). The youngest Late Quaternary reverse faults are mapped only in the southwestern Chuya depression and characterize a stage of uplift of the North Chuya Ridge that likely is related to isostatic processes (Buslov et al., 1996).

The northern extremity of Lake Teletskoye is controlled by a strike-slip fault along the West Sayan fault. The meridional part of the lake is largely superimposed on a belt of mylonitic schists (Sintubin et al., 1995; Buslov and Sintubin, 1995).

Lake Teletskoye is the best example of a late Pleistocene extensional basin in the Gornyy Altay. It formed as a local extension zone near the Mongolian-Altay and West Sayan microplate border (Figs. 6 and 7). Between the microplates, with different directions of compression-NNW-SSE and NNE-SSW, respectively-strike-slip displacements were induced, resulting in the formation of an extension zone within Lake Teletskoye (Delvaux et al., 1995d).

Seismic studies of the lake identified a sediment section about $1 \mathrm{~km}$ thick (Seleznyov et al., 1995). The Altay Quaternary stratigraphy and the lake-terrace sections (Markov, 1977) allow the upper horizon of sediments to be divided into four seismostratigraphic units (Fig. 6) that are separated by angular unconformities. The seismostratigraphic units are defined, successively, by (1) river-bed boulder and sand- 
A

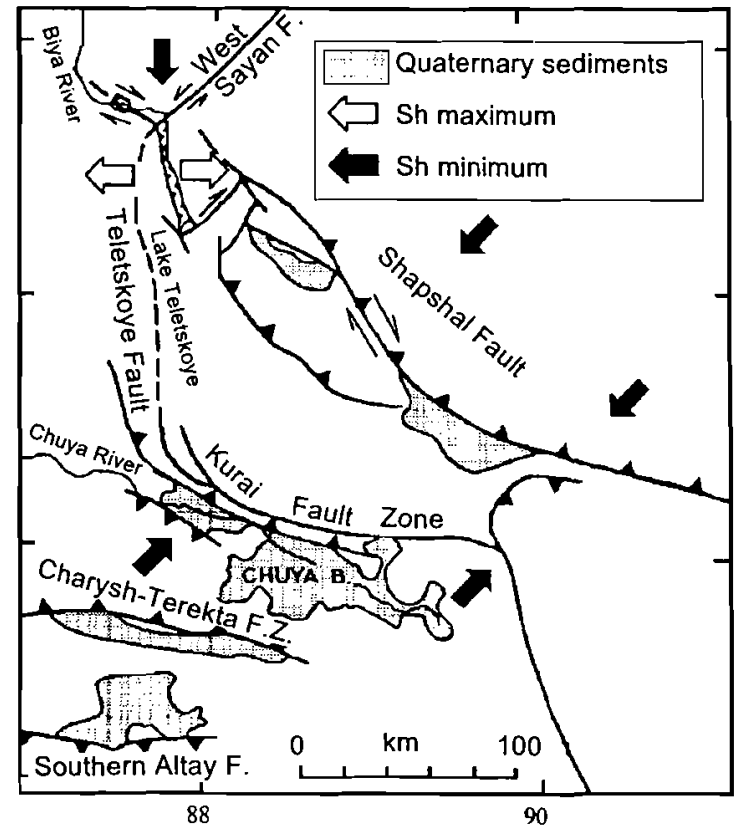

B

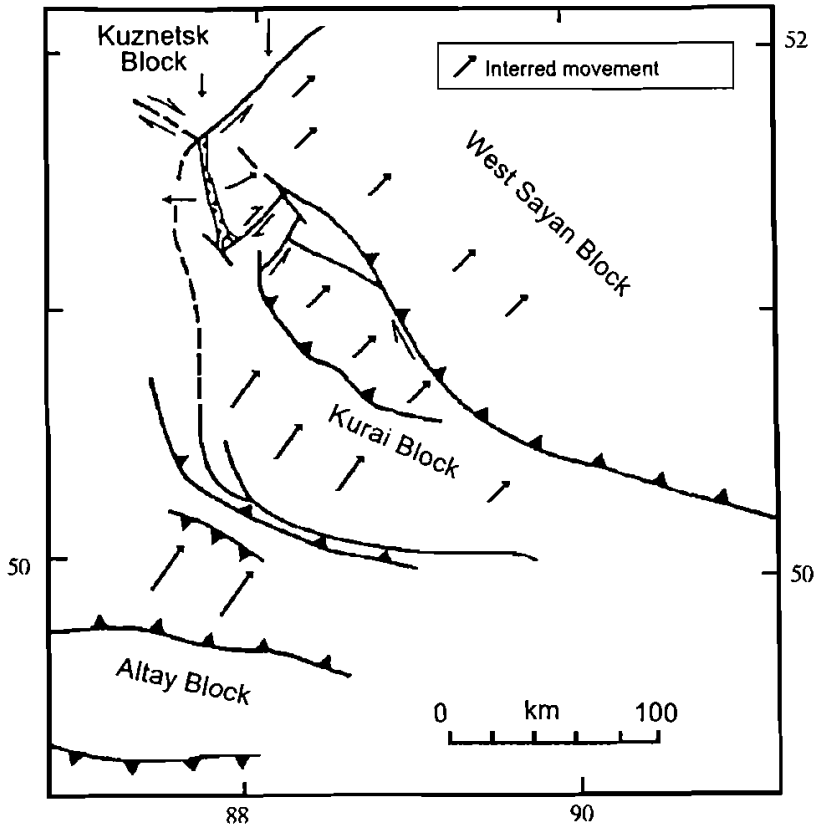

FIG. 6. Interpretation diagram of dynamics of the Lake Teletskoye depression. A. Kinematics of fault movement and regional horizontal stress directions. B. Model for relative movements of the blocks (Delvaux et al., $1995 d$ ).

conglomerate rocks $\left(\mathrm{N}_{2}-\mathrm{Q}_{1}, 0-120 \mathrm{~m}\right) ;(2)$ glacial and lacustrine deposits $\left(Q_{1-2}, 0-200 \mathrm{~m}\right) ;(3)$ moraine, lacustrine, and alluvial deposits $\left(Q_{3}\right.$, $100 \mathrm{~m})$; and (4) lacustrine and delta sediments $\left(Q_{4}, 30-40 \mathrm{~m}\right)$. The lower horizon of the lake sediments is difficult to divide and possibly is correlated with upper Neogene rocks of the Chuya depression.

Structural interpretation of seismic profiles of Lake Teletskoye and field studies of its shores enable us to propose a geodynamic environment and several evolutionary stages. Four seismic units and two fault systems of different age in the lake profile (Fig. 7) indicate a complex Pliocene-Quaternary tectonic setting of the Teletskoye area. Two distinct structural stages of basin formation can be identified-pre-Late Quaternary and Late Quaternary to the present. A more ancient stage can be seen in places, characterized by the faults along the northeastern side of the lake that are morphologically interpreted as reverse faults, the central zone of adjacent reverse faults, and the southern system of stepped faults. In the southern part of the lake, pre-Late Quaternary submeridional faults responsible for the formation of the middle Quaternary graben are recognized. Late Quaternary-present normal faults inherit a middle Quaternary graben and induce the subsidence of the northern part of Lake Teletskoye. For that time, the strike-slip movements along the Sayan fault are recorded. The Sayan fault can be regarded as a main strike-slip fault adjacent to which the extension zone in the submeridional part of the lake has opened. The structures of the Teletskoye graben probably reflect the rotational movements of the East Teletskoye block along the Sayan fault (Delvaux et al., 1995d; Dergunov, 1972; Klerkx et al., 1996).

\section{Comparison of the Tectonic Evolution of the Altay, Baikal Region, and Tien Shan}

Geologic events in the evolution of the KuraiChuya depression and Lake Teletskoye appear to be synchronous with those active in the Baikal rift zone (Delvaux et al., 1995b) $2000 \mathrm{~km}$ to the east. The Altay structures are located at the margin of the Mongolian plate, and the Baikal rift zone belongs to the Amur microplate margin. The synchronism of geologic events provides evidence for the interlinking of the migration and rotation of the Mongolian and Amur microplates. The Kurai-Chuya depres- 

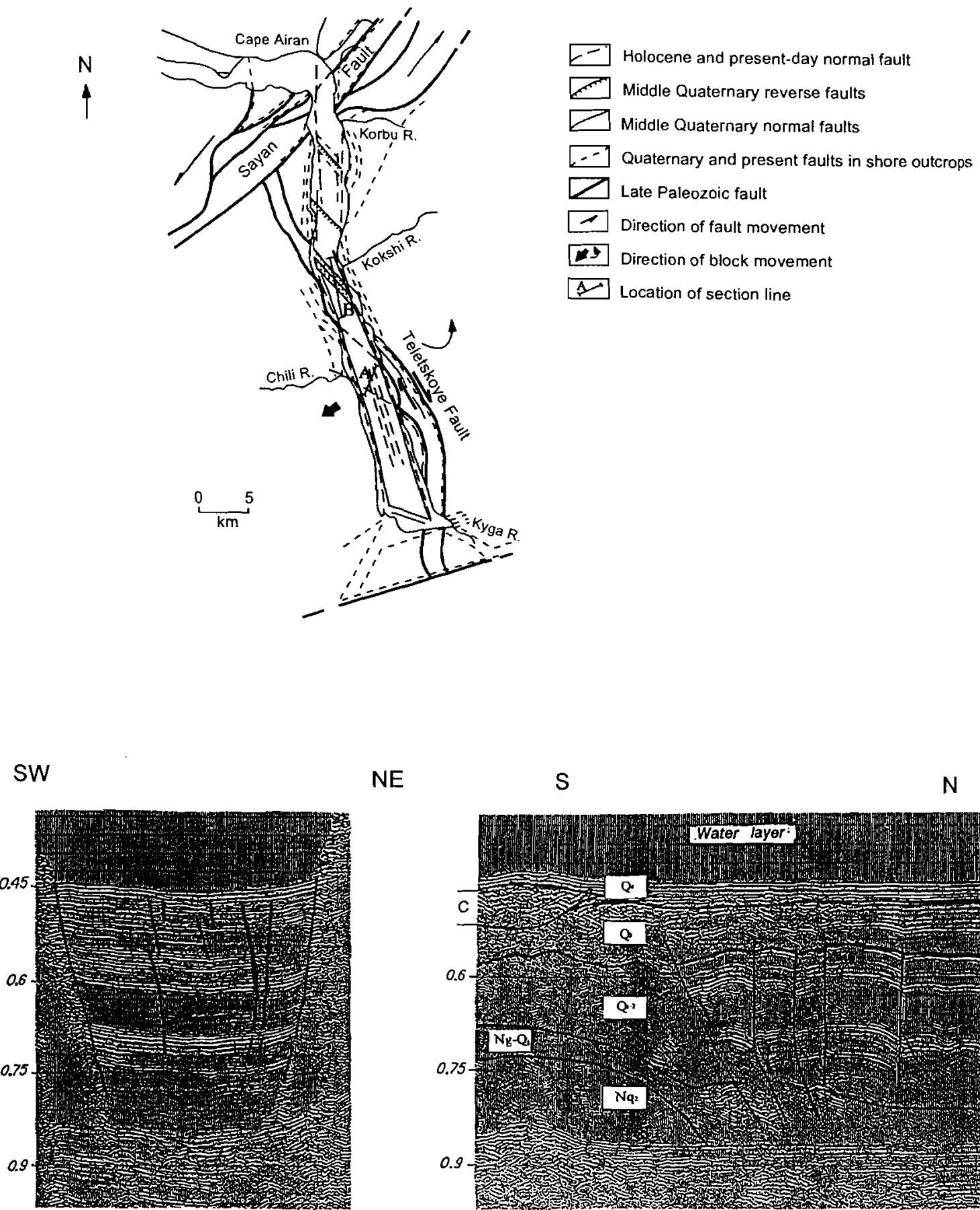

NE

S

N

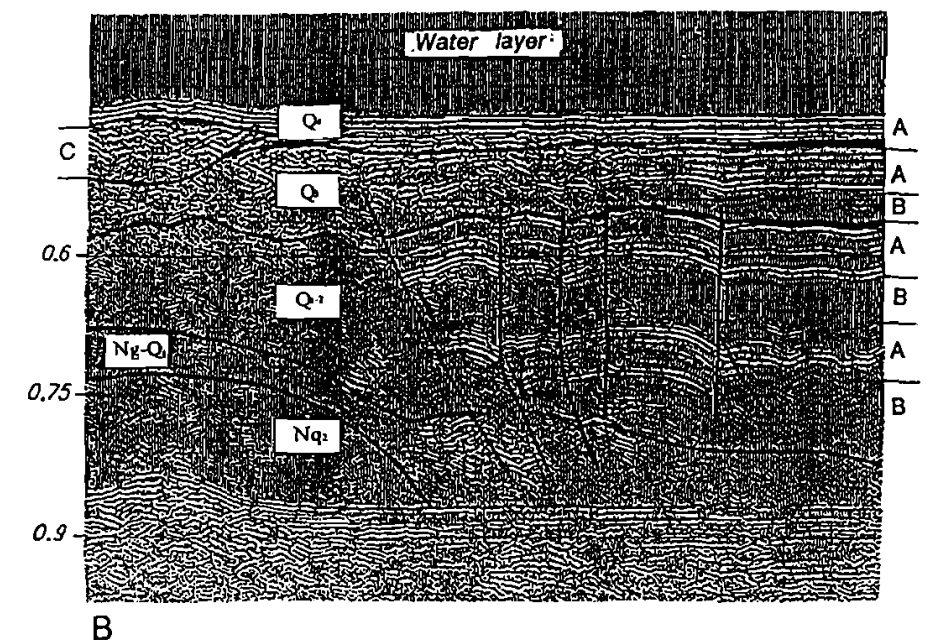

A

B

$\mathrm{Nq}_{q_{2}}$ Supposed Pliocene

Ng-Q Eopleistocene

Qis Lower-Middle Pleistocene
$Q_{1}$ Upper Pleistocene
Boundaries of seismic complexes
Q. Holocene
Faults
A B C Facies: $A=$ clay-siltstone; $B=\square$ Direction of fault movement $\mathrm{C}=$ delta unit of the Kokshi River

FIG. 7. Faults of Lake Teletskoye and seismic cross-sections (after Seleznyov et al., 1995). 


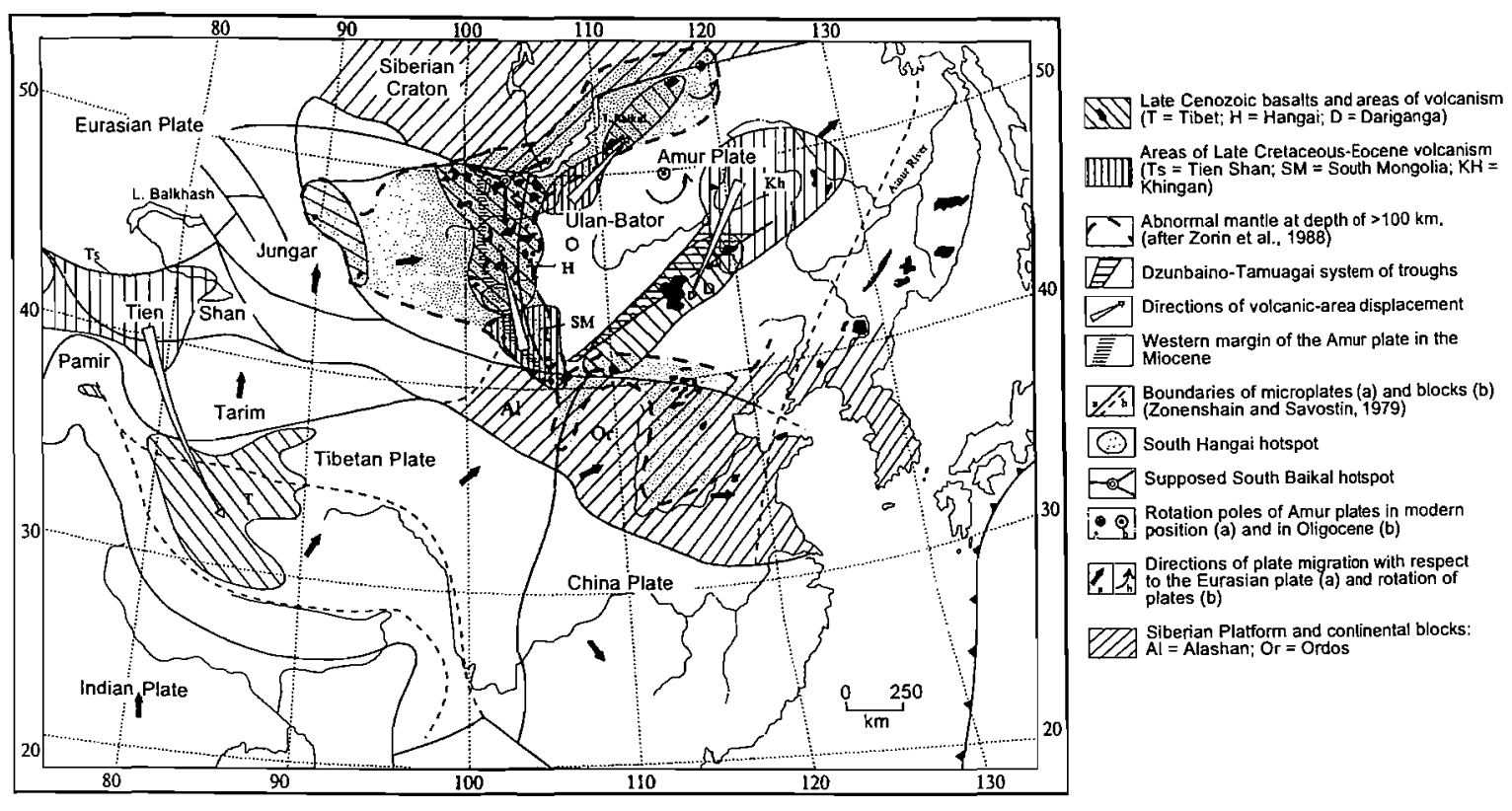

Fig. 8. Tectonic scheme and location of Upper Cenozoic basalts in eastern Central Asia (after Yarmolyuk et al., 1991).

sion and the Baikal rift zone may be characterized by the following tectonic and climatic processes (Logachev, 1993; Kazmin et al., 1995): (1) peneplanation and weathering $\left(K_{2}-\right.$ $\left.\mathrm{Pg}_{1}\right)$; (2) redeposition of the weathering crust into small isolated depressions $\left(\mathrm{Pg}_{2}\right) ; \quad$ (3) "slow" vertical movements, resulting in rift structures and lacustrine depressions $\left(\mathrm{Pg}_{3}-\mathrm{N}_{\mathrm{l}}\right)$ similar to the lacustrine stage of the Chuya depression; (4) "rapid" movements marking the stage of rapid riftogenic processes in the Baikal, Tunka, and Khubsugul depressions $\left(\mathrm{N}_{1}{ }^{2}-\mathrm{Q}_{1}\right)$; and (5) a late Quaternary stage of intense orogeny. Generally, the growth of the mountains of the Baikal region and the accumulation of coeval coarse-clastic sediments began at $3 \mathrm{Ma}$ (Logachev, 1993)-i.e., at the same time as in the Altay.

A system of grabens (Khubsugul, Tunka, Taryat) in central Mongolia (Yarmolyuk et al., 1991) is regarded as a system of extensional zones formed in the late Miocene-Pliocene as a result of strike-slip deformations along the border of the Amur microplate. In the Gornyy Altay, the western margin of the Mongolian microplate is outlined by the Kurai-Chuya graben system resulting from strike-slip deformations along the Charysh-Terekta and Kurai faults (Figs. 2 and 3 ). The present border of the Mongolian microplate was displaced eastward along the Shapshal and Kurai fault systems. The border is defined by related deformations (strike-slip fault/thrust-graben), such as the late Pliocene-Quaternary Teletskoye trough, for example, and is associated with present earthquake sources (Zhalkovskiy et al., 1995).

In the Oligocene, the geodynamic environment of Central Asia was defined by a counterclockwise rotation of the Amur microplate (Fig. 8) and the action of mantle plumes on the lithosphere (see below). The migration of mantle plumes reached a maximum at 25 to $30 \mathrm{Ma}$, when compressional tectonics began to affect the Amur microplate. If a microplate migrating over asthenospheric plumes existed in a tectonic-extension setting, it would result in the formation of a lithospheric "window" and uplifting of abnormally hot mantle. This induced a migration of volcanic centers from the South Mongolian field toward the HangaiBaikal field. It is worth noting that volcanism is lacking, although in the Altay, extension occurred and Cenozoic depressions formed. This lack of volcanism supports the hypothesis of inherited plume magmatism in Central Asia only in areas overlying more ancient hot spots.

\section{Pamir-Tien Shan region}

The structural features of the Pamir-Tien Shan region have been reported elsewhere 
(Bazhenov and Burtman, 1982; Burov et al., 1990; Sadybakasov, 1990; Zonenshain et al., 1990; Thomas et al., 1993; Molnar et al., 1994; etc.). In general, there are two types of structural domains separated by the Talas-Fergana fault zone (Fig. 1); all seem to be closely related to the India-Eurasia collision and its kinematics.

Basement rocks exposed over at a distance of more than $1000 \mathrm{~km}$ north of the Tien Shan indicate inactive strike-slip faults of Paleozoic age (Suvorov, 1968). Paleozoic deformation left a fabric that Cenozoic tectonics has utilized; however, much of this Paleozoic fabric seems to have been unaffected by Cenozoic deformation. The present mountain-building stage may have taken advantage of thinned or weakened lithosphere. Potential weaknesses include strike-slip faults, such as the Talas-Fergana fault, active in Paleozoic time (Burtman, 1964, 1975) but currently strike-slipping at $10 \mathrm{~mm} / \mathrm{a}$ (Burtman et al., 1995), and also a hot mantle diapir under the central and eastern Tien Shan (Roecher et al., 1993).

The distribution and lithology of Mesozoic deposits and their inferred paleocurrent directions provide arguments that the Tien Shan was active during the Mesozoic. Long, narrow basins with thick Jurassic sequences along the Talas-Fergana fault suggest a pull-apart mechanism of Mesozoic strike-slip along that fault (Burtman, 1964, 1975; Sobel, 1995).

The present structure of the Tien Shan consists of roughly $\mathrm{E}-\mathrm{W}$-trending mountain ranges separated by sedimentary basins. Fault-plane solutions of earthquakes attest to continued thrust faulting, commonly on steeply dipping planes $\left(30\right.$ to $45^{\circ}$ ) (e.g., Shirokova, 1974; Ni, 1978; Nelson et al., 1987; Mellors, 1995). In contrast, numerous thrust faults involving Cenozoic strata within the basins display a flatramp geometry that requires low-angle detachment of strata at shallow levels. Boundaries between ranges and basins are either gradual, with tilted pre-orogenic surfaces covered by basin sediments, or sharp and marked by thrust faults.

Just south of the Kyrgyz Tien Shan, a foldand-thrust belt suggests coherent underthrusting of the Tarim Basin beneath the southern margin of the Tien Shan (e.g., Burov et al., 1990). Farther east within China, wide fold-andthrust belts bound both sides of the Tien Shan
(Hendrix et al., 1994). In Kyrgyzstan, the northern boundary of the range is abrupt and is defined by a narrow zone of folds and thrust faults, without clear evidence of lithospheric flexure.

According to geological and kinematic data (e.g., Le Pichon et al., 1992), the Indian plate collided with southern Asia in the late Eocene, and during the period 35 to $60 \mathrm{Ma}$ it migrated northwestward over a distance of $870 \mathrm{~km}$. This movement and plate collision induced the recent deformation in the Pamirs, later propagating to the west and northwest. Judging by paleomagnetic and geological data (Bazhenov and Burtman, 1986), the arch-like structure of the Pamirs formed in post-Paleogene time because of the indentation of the Punjab zone of the Indian continent into Asia. As a result, the Pamirs moved northward, forming the thrusts associated with the eastern and western strike-slip faults. The Pamir compression was responsible for the formation of sinistral $\mathrm{E}-\mathrm{W}$ and NW strike-slip faults (Gissar, Kopet Dag, and others) and dextral movements of blocks and microplates. In the front, the Pamirs were thrust over the Tajik depression sediments and overlapped them for $300 \mathrm{~km}$. In the Miocene, the deformation reached the western Tien Shan, resulting in thrusts and strike-slip faults bounded on the northwest by the Talas-Fergana sinistral strike-slip fault and the central and eastern Tien Shan thrusts. During the Cenozoic, the western Tien Shan migrated northwestward along the Talas-Fergana fault and rotated counterclockwise $20 \pm 11^{\circ}$ relative to the central Tien Shan (Thomas et al., 1993).

The formation of thrusts and strike-slip faults in the central and eastern Tien Shan is related to the northward compression of the Tibetan Plateau and the Tarim plate, which were affected by the indenting Indian plate. Compressive E-W stresses between the stable Tarim and Junggar blocks, with N-S-striking borders, resulted in the formation of the central and eastern Tien Shan thrusts. Ramp and halframp structures of the Issyk-Kul', Naryn, and Aksay depressions formed there, filled with Cenozoic intermontane sediments.

For comparison, in the Cenozoic structure of the Altay, two stages of compression of different age, Eocene and Pliocene, can be recognized. For the Eocene, when the rotation of the southern Asian plates was maximal, no notable move- 
ments are reported in the Altay. In the Oligocene, intermontane depressions filled by red sandy-clayey and coarse-clastic rocks (Karakum suite and its analogues) formed. After the Oligocene-Miocene tectonically stable stage, in which lacustrine-marsh deposits accumulated (Kochagach, Tueryk, and Kyzylgir suites and their analogues), the stage of maximal deformation is recorded by PliocenePleistocene ( 3 to $1 \mathrm{Ma}$ ) strike-slip faults and their associated thrusts and grabens (Figs. 3, 4, and 6). The cause of Pliocene reactivation of tectonic processes still is unknown.

Although the entire structure of the Central Asian belt can be characterized by a common paragenesis of three structural modes (strikeslip faults, thrusts, and extension zones), the areal distribution of these structures differs. Our point is that the differences between the Central Asian structures depend on the relation of total compression direction to the trend of block boundaries. Thus, in the Pamirs and western Tien Shan, which were close to the maximum compression point of the Punjab "indenter" (Molnar and Taponier, 1975), deformation occurred as oblique thrusts, thrusts, and $\mathrm{N}$-verging folds. East of the Talas-Fergana sinistral strike-slip fault, variable deformation occurred. There, northward compression induced by the migration and rotation of Tibet (Avouac et al., 1993) resulted in the uplift of the Tien Shan along thrusts and oblique thrusts (Cobbold and Davy, 1988; Huafu et al., 1994), since the compression was perpendicular to the boundary of the Tarim and Junggar plates bordering the Tien Shan.

Between the Junggar plate and Siberian craton, compression directions are oblique to the borders of stable bodies. This caused the formation of strike-slip faults in western Mongolia, central Kazakhstan, the Altay, and Sayan. In the Tibet and Amur microplates, extension zones in the back of the rotating plates coincided with the sites of pre-existing mantle plumes; this resulted in a combination of rifts, grabens, uplifts, and strike-slip faults.

The remote location of the Altay relative to the Himalayas and the absence of mantle plumes is clear. The next section of the paper reviews the development of the Tien Shan, Tibet, the Baikal volcanic areas, and the Amur plate in the Cenozoic, in order to demonstrate their linkages with mantle plumes and to show the action of the latter on the lithosphere.

\section{Fission-Track Age Analysis}

Apatite fission-track thermochronology has been used to study intraplate vertical movements in the Himalayas, Tibet, Tien Shan, and Baikal regions. Some important results for the Tien Shan and Baikal region are presented in Table 1; they are important in understanding the tectonic evolution and morphotectonics of two typical regions from different parts of the Central Asian orogenic belt (Molnar et al., 1994; Van der Beek et al., 1996).

The combination of the numbers of fission tracks and their lengths (Fig. 9) measures the cooling history of exposed rocks within a narrow, low-temperature interval of 60 to $110^{\circ} \mathrm{C}$. The incision into the pre-orogenic surface is more than $2 \mathrm{~km}$ in many ranges, raising the question of whether the rocks have passed through the $110^{\circ}$ isotherm during the Cenozoic. In the Tien Shan, the combination of ages and track lengths reveals that some areas were heated above the apatite-annealing isotherm during Cenozoic time, at 28 to $32 \mathrm{Ma}$ along the Talas-Fergana fault and at 12 to $18 \mathrm{Ma}$ in the central part of the Kyrgyz Range. Fissiontrack data indicate significant differences across the Kyrgyz Range (12 to $18 \mathrm{Ma}$ in the core, older along the flanks). Most of the older dates for the Kyrgyz Range and along the TalasFergana fault belong to the latest Cretaceous-Eocene interval ( 80 to $58 \mathrm{Ma}, 61 \mathrm{Ma}$ on average), and in the other areas they are much older (100 to $163 \mathrm{Ma}$; one date is $246 \mathrm{Ma}$ ).

In the Baikal region, recent Cenozoic dates have not been recorded. Ages younger than 100 $\mathrm{Ma}(57$ to $86 \mathrm{Ma}$, close to 58 to $80 \mathrm{Ma}$ in Tien Shan) were encountered in samples from the Primorskiy fault scarp. Most samples have AFT ages between 100 and $140 \mathrm{Ma}$, with relatively high mean track lengths $(13.2 \mathrm{~mm})$, and show that fission track ages (57 to $140 \mathrm{Ma}$ ) change with elevation. The older dates ( 145 to $227 \mathrm{Ma}$ ) exhibit no correlation with elevation (Fig. 9A). In the plot of mean track lengths versus AFT ages for both regions (Fig. 9B), three groups of dates can be identified. The oldest dates for both regions define a trend from $230 \mathrm{Ma}(13.8 \mathrm{~mm})$ 
TABLE 1. Apatite Fission-Track Ages of the Baikal Mountains and Tien Shan

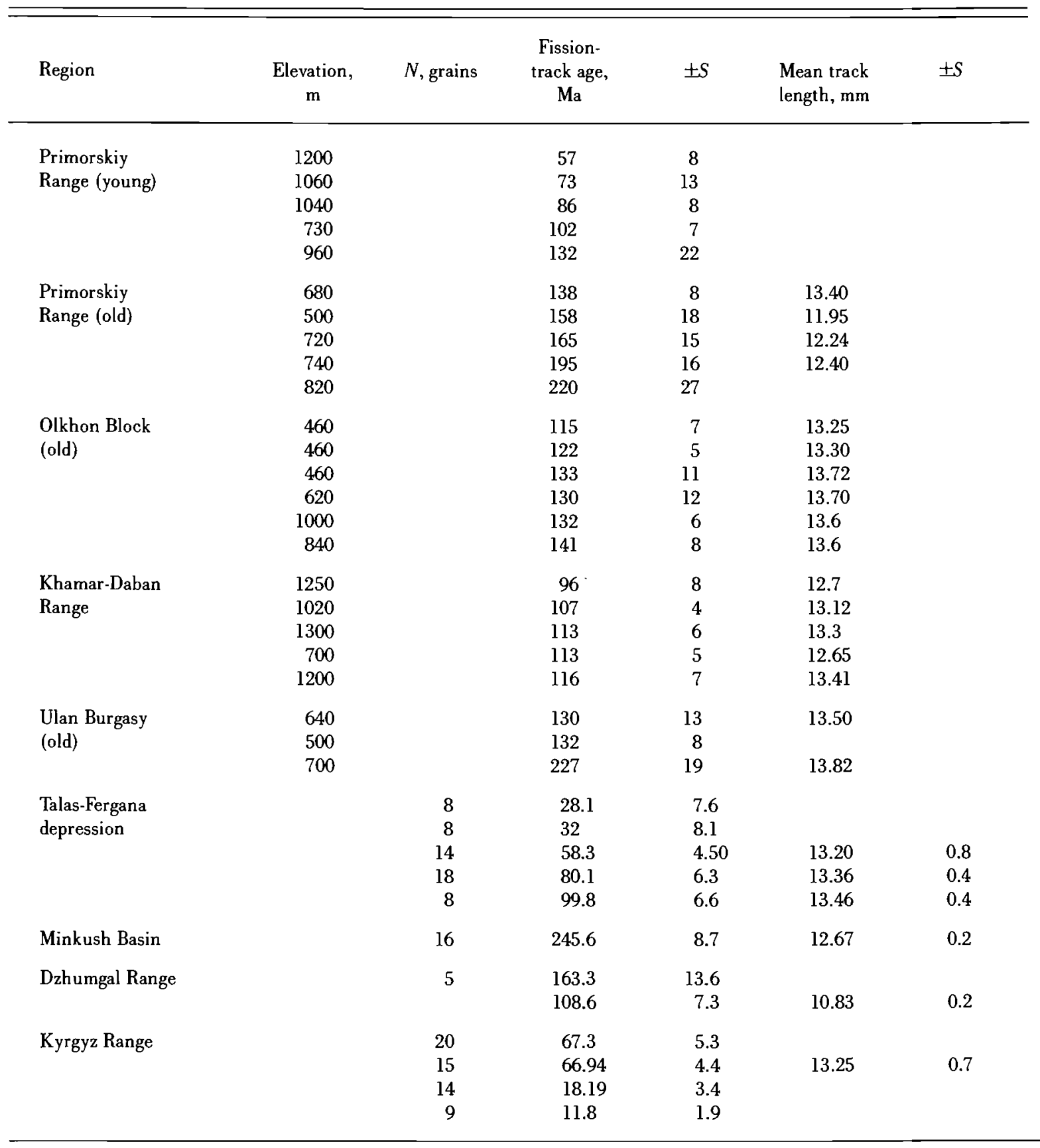

Sources: Molnar et al., 1994; Van der Beek et al., 1996.

down to $110 \mathrm{Ma}(10.9 \mathrm{~mm})$. Most samples from the Baikal region fall on the trend of decreasing track length from $140 \mathrm{Ma}(\sim 13.7 \mathrm{~mm})$ down to 90 to $100 \mathrm{Ma}$ (12.0 to $12.6 \mathrm{~mm})$. The third group possibly relates to recent dates for the Tien Shan (Fig. 9B).

For interpretation, we can use a model supported by Crowley et al. (1991) and Van der Beek (1995). The model implies that each track formed characterizes a different thermal history of the host rocks and shows a different annealing (shortening). The evolution of cooling samples may be used for calculating the degree of erosion and related vertical movements. Rapid cooling from temperatures more than $120^{\circ} \mathrm{C}$ at nearly 100 to $110 \mathrm{Ma}$ is typical of most of the samples from the Baikal region. A similar model shows that slow cooling from 


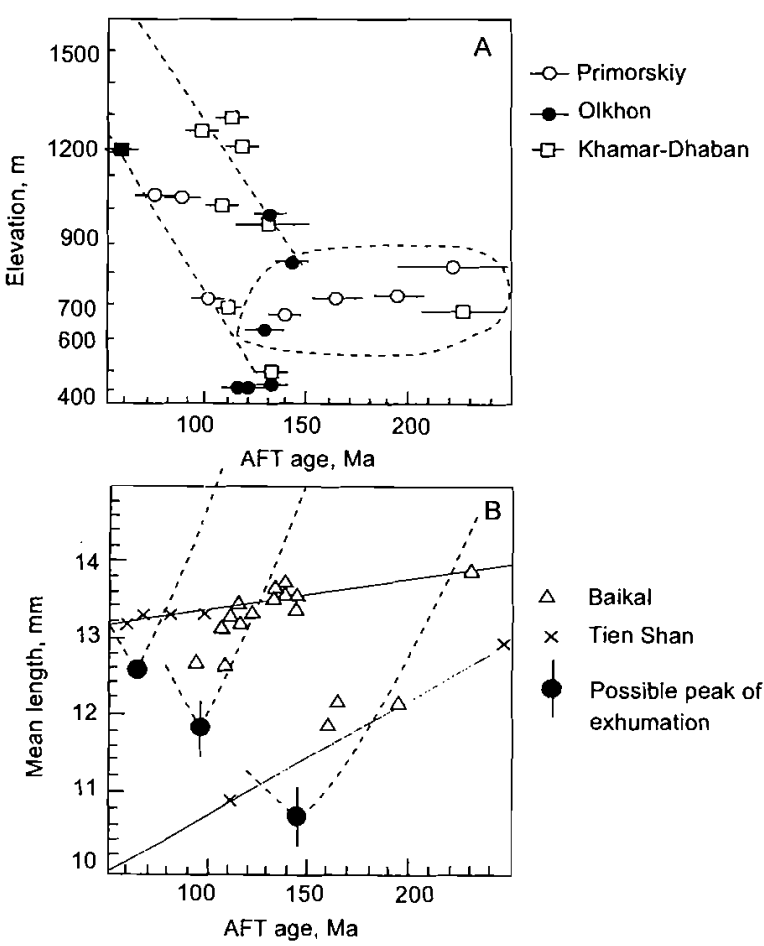

Fic. 9. Apatite fission track (AFT) data on the Baikal region and the Tien Shan (compiled from Van der Beek et al., 1996; Molnar et al., 1994).

higher temperatures at nearly 200 to $230 \mathrm{Ma}$ to $60^{\circ} \mathrm{C}$ at nearly 140 to $150 \mathrm{Ma}$ is typical of many ranges from the Baikal and Tien Shan regions. The model for the youngest exposed rocks is difficult to construct, reflecting scarcity of data, but the third peak of exhumation possibly relates to a $60-\mathrm{Ma}$ event.

Thus the AFT data suggest three cooling and exhumation phases during the Cretaceous and early Eocene. Possibly, they are contemporaneous with the climax of compressional Late Mesozoic tectonics. The phases of 100 to 110 $\mathrm{Ma}$ and $60 \mathrm{Ma}$ correlate with the peaks of preOligocene basaltic magmatism in both regions. The AFT data indicate that the onset of exhumation began in the Jurassic and Early Cretaceous. Little erosional denudation has affected the flanks adjacent to the central Baikal rift in the Cenozoic. More intense Cenozoic denudation is recorded in some Tien Shan ranges.

\section{Cenozoic Tectonics and Mantle-Plume Magmatism}

In Central and East Asia, several fields of Cenozoic alkaline-basaltic magmatism may be related to the Cenozoic activity of mantle plumes. The fields can be grouped into three pairs of interlinked mantle magmatism areas, described below:

1. Moderate- and high-potassium Late Cretaceous-Paleogene magmatism in the Tien Shan area (40 to $113 \mathrm{Ma}$ ) (Dobretsov and Zagruzina, 1977; Sobel, 1995) and Late Cenozoic magmatism in Tibet $(0.5$ to $28 \mathrm{Ma})$ and the eastern Pamirs (12 to $24 \mathrm{Ma}$ ) (Dmitriyev, 1976; Arnaud et al., 1992).

2. Late Cretaceous-Paleogene magmatism in southern Mongolia (30 to $80 \mathrm{Ma}$ ) and Late Cenozoic magmatism in the Hangai and Transbaikal areas ( 0 to $25 \mathrm{Ma}$ ), both belonging to the Mongolian superplume (Windley and Allen, 1992); possible interlinks include the Burkal and Vitim areas in western Transbaikal ( 30 to 73 and 1 to $19 \mathrm{Ma}$ ) and Udokan area (0 to $14 \mathrm{Ma})$.

3. Cretaceous-Paleogene basaltoids of the Khingan area of northeastern China (50 to 60 and 20 to $30 \mathrm{Ma}$ ) and Miocene-Quaternary basalts of the Dariganga area ( 0 to 8 $\mathrm{Ma}$.

The distribution and the ages of volcanics in those areas are shown in Figs 8, 10, and 12 to 14 .

Other areas of Neogene-Quaternary basalts-e.g., the nearby Sikhote-Alin (Russia), Sea of Japan, and Bohai Bay (China) (Fig. 8) are not considered here. They are too distant from the active intracontinental orogenic zones, and they are associated with Late Cretaceous-Paleogene subduction volcanics relating to the Andean-type Katasian belt.

\section{The Tien Shan area}

Late Cretaceous-Paleogene, predominantly alkaline basalts, alkaline ol-basalts (less trachyandesites), and dikes and diatremes of limburgites and augitites occur mainly within the Kyrgyz Tien Shan (less in its periphery) in the northern Tarim block (Tuyun basin), at the southern slopes of Kazakhstan's Junggar, and in the southern Fergana depression in Kyrgyzstan and Uzbekistan. Locations, rock types, and rock ages are listed in Table 2 and Figure 10.

The volcanic rocks are distributed mostly in the Issyk-Kul', Naryn, and Aksay depressions, the Baiduly-Moldotau Range, and in the Tuyun basin in the north western Tarim block (Fig. 10). 


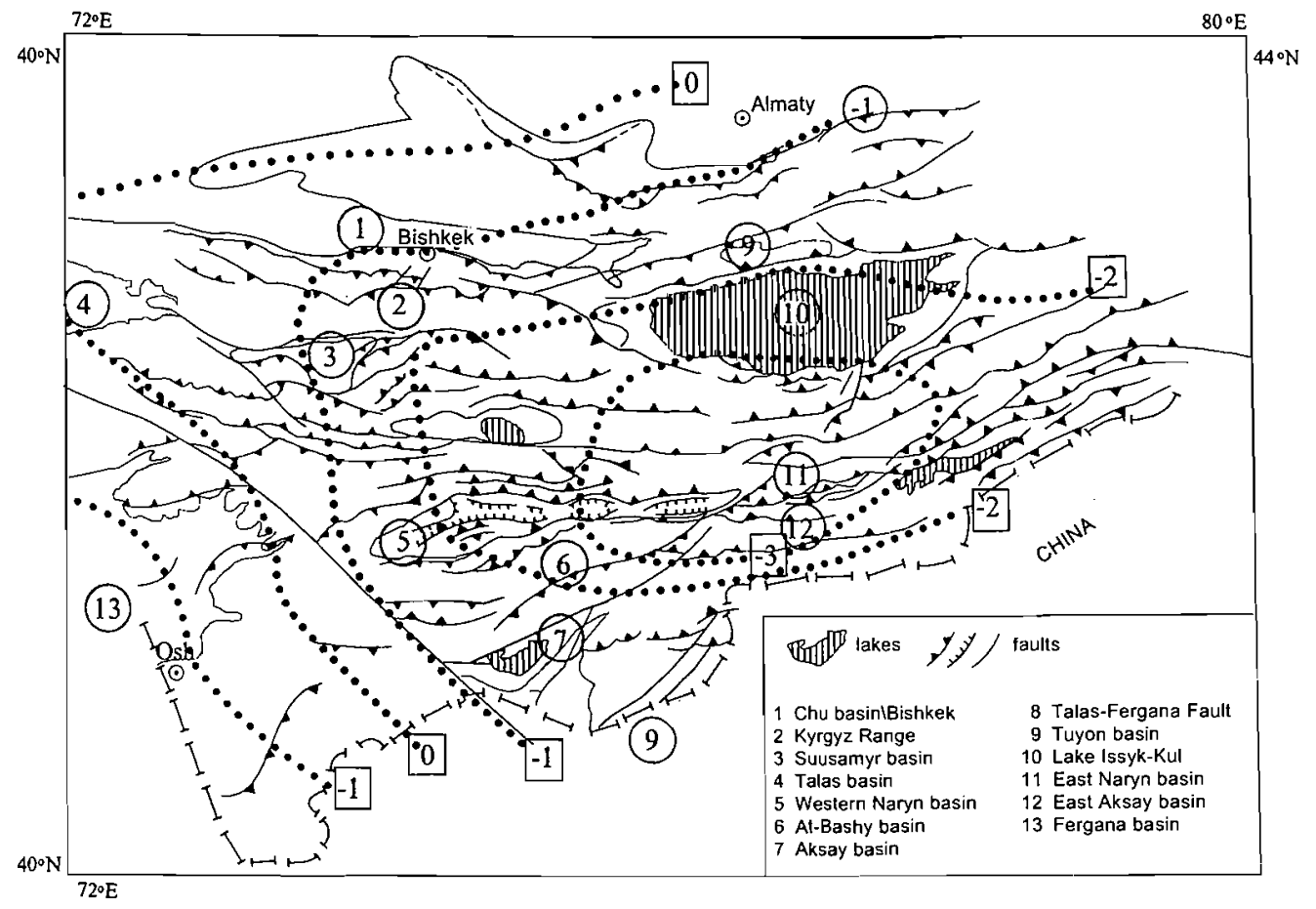

FIG. 10. Structural scheme of the Tien Shan and fields of plume magmatism. Points outline a present-day hot mantle, deviation $\Delta \mathrm{V}_{\mathrm{p}}=1-3 \%$. Most basins and ranges $(1-13)$ contain pre-Oligocene basaltic lavas, dikes, and diatremes.

Age maxima are 89 to 113,55 to 77 , and 42 to 53 Ma. The first two maxima also are recorded by apatite fission-track ages of 109 and 58 to 67 Ma, along with younger fission-track values of 12 to $18 \mathrm{Ma}$, characterizing the age of the orogeny (Molnar et al., 1994). Most of the basalts are related to the lower section of the Upper Cretaceous-Cenozoic continental basaltred formation (Dobretsov and Zagruzina, 1977; Dobretsov, 1979; Afonichev and Vlasov, 1984). The youngest dikes and diatremes are of 42 to $48-\mathrm{Ma}$ age. Mantle xenoliths, such as carbonatized lherzolites and pyroxenites, are present in diatremes, and less so in basalts.

Geochemical composition and isotopic ratios do not indicate any contamination by crustal material (Table 3). These rocks are similar to alkaline basalts of oceanic islands of the Hawaiian type. According to the $\mathrm{Nd} / \mathrm{Sr}$-isotopic ratio, the Tuyun basalts lie between the average composition of the Earth and the field of MORB (Sobel, 1995). Therefore, these alkaline basalts may originate by low-grade melting of a source (mantle plume) similar to that beneath the Hawaiian Islands.

Whether some relation exists between the Late Cretaceous-Paleogene magmatism in the
Tien Shan and the present hot mantle anomaly beneath it is not yet clear (Roecker et al., 1993). In Figure 10, the center of the hot mantle area with $\Delta \mathrm{V}_{\mathrm{p}}=1$ to $3 \%$ is shown to occur in an area of earlier mantle magmatism. Apparently, when the Indian-Australian plate collided with Asia, a mantle plume beneath the Tien Shan already existed. The plume probably was responsible for the weakened lithosphere beneath the Tien Shan and the formation of the first generation of mountains. The latter is recorded in basal conglomerates of the second (EoceneOligocene) terrigenous formation (Afonichev and Vlasov, 1984) and apatite fission-track ages of 58 to $67 \mathrm{Ma}$ (Molnar et al., 1994). After collision and probable rotation of the Tibetan plate, mantle magmatism moved to the southeast toward the eastern Pamirs, Karakorum, and Tibet. Therefore, regeneration of hot mantle should be related not to the plume, but to the heating of a thickened crust.

\section{The Tibetan volcanic area}

The Tibetan volcanic area is bounded by the Altyn-Tag fault zone on the north and by the Karakorum fault on the south and southwest; it 
TABLE 2. Ar-Ar and K-Ar Ages of Upper Cretaceous-Paleogene Volcanic Rocks of the Tien Shan

\begin{tabular}{|c|c|c|c|}
\hline Region & Rock & $\mathrm{Ar}-\mathrm{Ar}$ and $\mathrm{K}-\mathrm{Ar}$ ages, $\mathrm{Ma}$ & Source \\
\hline Talas depression & alkaline basalt & $42-50$ & $\begin{array}{l}\text { Dobretsov and Zagruzina, } \\
1977\end{array}$ \\
\hline $\begin{array}{l}\text { Uchkuduk diatreme, Issyk- } \\
\text { Kul' depression }\end{array}$ & limburgite & $42,48,53$ & \\
\hline $\begin{array}{l}\text { Southeastern Issyk-Kul' } \\
\text { depression }\end{array}$ & $\begin{array}{l}\text { olivine basalt and } \\
\text { limburgite }\end{array}$ & $48-53$ & \\
\hline $\begin{array}{l}\text { Northwestern Issyk-Kul' } \\
\text { depression }\end{array}$ & alkaline basalt & $55-89$ & Krylov and Silin, 1963 \\
\hline Moldotau ranges & $\begin{array}{l}\text { olivine basalt, olivine } \\
\text { trachybasalt }\end{array}$ & 48,55 & $\begin{array}{l}\text { Dobretsov and Zagruzina, } \\
1977\end{array}$ \\
\hline Naryn depression & $\begin{array}{l}\text { augitite and limburgite } \\
\text { dikes }\end{array}$ & 103,105 & \\
\hline Aksay depression & $\begin{array}{l}\text { alkaline basalt and } \\
\text { limburgite pipe }\end{array}$ & $52,63,77$ & \\
\hline Tarim block, Tuyun basin & $\begin{array}{l}\text { lamprophyre, diabase and } \\
\text { gabbro sills }\end{array}$ & $46,59-67$ & Sobel, 1995 \\
\hline Tarim block, Tuyun basin & olivine basalt & $89-113$ & \\
\hline $\begin{array}{l}\text { Southern margin of the } \\
\text { Fergana depression }\end{array}$ & $\begin{array}{l}\text { alkaline basalt, limburgite } \\
\text { dikes }\end{array}$ & $\begin{array}{c}80-55 \mathrm{Ma} \\
\text { (stratigraphic ages) }\end{array}$ & Molnar et al., 1994 \\
\hline
\end{tabular}

has a rough border near $90^{\circ} \mathrm{E}$. Long. in the east (Arnaud et al., 1992). The small eastern Pamir area lies west of the Karakorum strike-slip fault (Dmitriyev, 1976). As the Altyn-Tag fault zone is dextral and the Karakorum fault is sinistral, Tibet has a general southeastward movement. This accords with the distribution of Cenozoic volcanics of different age, the oldest being recorded in the southeastern zone (15 to $20 \mathrm{Ma}$, the Lhasa block) and west of the Karakorum strike-slip fault, in the eastern Pamirs (14 to $26 \mathrm{Ma})$. The youngest ages $(0.5$ to $5 \mathrm{Ma})$ are recorded in the northern Kunlun block (Table 4).

To the south and west, the Tibetan area is bounded by Upper Cretaceous-Eocene calcalkaline acid volcanics and Miocene collisional granites. The former are related to crustal subduction beneath the Tibetan block prior to the India-Asia collision.

The composition of lavas from Tibet and the eastern Pamirs varies from trachybasalts to rhyolites and alkaline leucite-bearing rocks (Fig. 11). They all have high, but variable, $\mathrm{K}_{2} \mathrm{O}$ contents and positive $\mathrm{K} / \mathrm{Na}$ ratios (Table 3 ). Three series of rocks are distinguished-mod- erate-potassium subalkaline, and intermediateand high-potassium alkaline (fergusite, leucitites, etc.). They are rich in mobile trace elements (Ba, Rb, $\mathrm{Zr}$ ) and REE (600 times higher than the chondritic level for La). Stable contents of Sr- and Nd-isotopes $\left({ }^{87} \mathrm{Sr} /{ }^{86} \mathrm{Sr}=0.708\right.$; ${ }^{143} \mathrm{Nd} /{ }^{144} \mathrm{Nd}=0.5123$ to 0.5124 ) contrast with high $\mathrm{Pb}$-isotopic variations. Judging by $\mathrm{Sr} / \mathrm{Nd}$ isotopic ratios, the lavas of Tibet are comparable to the K-richest lavas of the Roman province and fall close to the field of lamproites (Fig. 11C). Such a source, rich in trace elements and $\mathrm{Sr}$ - and Nd-radiogenic isotopes, could represent either a young subcontinental mantle (Arnaud et al., 1992) or a deep mantle plume close to that in the lamproite field (Foley et al., 1987).

\section{Southern Mongolian area}

The southern Mongolian area of Late Cretaceous-Paleogene magmatism is located in the eastern Gobi Altay and Gobi Tien Shan, at the attenuation of the present orogenic ranges. To the northeast, it grades into the Hangai and southern Baikal areas with Late Cenozoic mantle magmatism (Fig. 12). A smaller and isolated area of Late Cretaceous-Eocene volcanics 
TABLE 3. Major-and Trace-Element Compositions of Representative

Cenozoic Volcanics of Northwestern Tibet and the Pamirs

\begin{tabular}{|c|c|c|c|c|c|c|c|c|c|c|}
\hline \multirow[b]{2}{*}{ Component } & \multirow[b]{2}{*}{ B-185 } & \multirow[b]{2}{*}{ B-186 } & \multicolumn{3}{|c|}{ Northwestern Tibet } & \multirow[b]{2}{*}{ TA.200 } & \multirow[b]{2}{*}{197} & \multirow[b]{2}{*}{$\mathrm{Xl}$} & \multirow{2}{*}{$\begin{array}{c}\text { Pamir }{ }^{1} \\
\text { X2 }\end{array}$} & \multirow[b]{2}{*}{$5 \mathrm{Gl}$} \\
\hline & & & TA-191 & T.192 & T-193 & & & & & \\
\hline $\mathrm{SiO}_{2}$ & 51.42 & 49.6 & 56.95 & 57.5 & 57.09 & 56.67 & 75.1 & 52.32 & 45.65 & 49.24 \\
\hline $\mathrm{Al}_{2} \mathrm{O}_{3}$ & 14.62 & 13.65 & 14.1 & 14.15 & 14.31 & 13.8 & 12.95 & 15.89 & 12.71 & 14.95 \\
\hline $\mathrm{Fe}_{2} \mathrm{O}_{3}$ & 3.35 & 3.27 & 2.86 & 2.82 & 2.81 & 2.93 & 1.6 & 4.86 & 4.86 & 6.16 \\
\hline $\mathrm{FeO}$ & 3.02 & 2.94 & 2.57 & 2.54 & 2.53 & 2.64 & 1.44 & 1.6 & 2.55 & 6.16 \\
\hline $\mathrm{MgO}$ & 4.03 & 5.6 & 3.8 & 3.36 & 3.67 & 4.37 & 0.04 & 1.4 & 3.94 & 2.13 \\
\hline $\mathrm{CaO}$ & 7.59 & 7.2 & 6.45 & 5.85 & 6.74 & 6.35 & 0.6 & 5.73 & 13.5 & 7.14 \\
\hline $\mathrm{Na}_{2} \mathrm{O}$ & 4.68 & 3.8 & 3.89 & 4.1 & 4.06 & 4.02 & 4.35 & 2.84 & 1.46 & 4.58 \\
\hline $\mathrm{K}_{2} \mathrm{O}$ & 4.77 & 4.7 & 4.75 & 5.15 & 4.99 & 5.4 & 4.95 & 8.33 & 6.87 & 10.56 \\
\hline $\mathrm{TiO}_{2}$ & 1.85 & 1.77 & 1.36 & 1.32 & 1.31 & 1.43 & 0.1 & 0.94 & 1.17 & 0.96 \\
\hline $\mathrm{P}_{2} \mathrm{O}_{5}$ & & 1.25 & 0.99 & 0.97 & & & 0.04 & 0.18 & 1.09 & 0.9 \\
\hline $\mathrm{MnO}$ & 0.14 & 0.12 & 0.1 & 0.09 & 0.09 & 0.1 & 0.01 & 0.19 & 0.13 & \\
\hline $\mathrm{H}_{2} \mathrm{O}^{+}$ & 2.8 & 3.8 & 0.76 & 0.7 & 0.9 & 0.2 & 0.5 & 5.38 & 5.15 & 1.72 \\
\hline $\mathrm{H}_{2} \mathrm{O}^{-}$ & 0.29 & 0.35 & 0.25 & 0.45 & 0.14 & 0.12 & 0 & 0.41 & 0.46 & \\
\hline Total & 99.76 & 100.24 & 100.01 & 99.84 & 99.66 & 99.04 & 99.49 & 100.16 & & 99.97 \\
\hline $\mathrm{Sr}$ & 2011 & 1756 & 1410 & 1397 & 1368 & 1567 & 64 & 4100 & 4650 & \\
\hline $\mathrm{Ba}$ & 2563 & 2564 & 2080 & 2091 & 1760 & 2076 & 86 & 0.47 & 1.37 & \\
\hline $\mathbf{R b}$ & 122 & 178 & 120 & 187 & 193 & 196 & 1140 & 339 & 328 & \\
\hline Th & 27 & 24 & 48 & 49 & 50 & 44 & 66 & 99 & 61 & \\
\hline $\mathrm{HC}$ & 8 & 8.7 & 7.3 & 10 & 8.2 & 9.8 & 8.2 & & & \\
\hline $\mathrm{Zr}$ & 412 & 358 & 230 & 318 & 368 & 407 & 27 & 425 & 337 & \\
\hline Co & 24 & 32 & 30 & 35 & 19 & 20 & 0 & & & \\
\hline $\mathrm{Ni}$ & 72 & 64 & 70 & 59 & 58 & 61 & 9 & & & \\
\hline $\mathrm{Cr}$ & 88 & 122 & 137 & 109 & 81 & 83 & 3 & & & \\
\hline V & & 127 & 95 & 97 & & & & & & \\
\hline $\mathrm{La}$ & 177 & 183 & 137 & 156 & 151 & 161 & 79 & 185 & & \\
\hline $\mathrm{Ce}$ & 333 & 368 & 263 & 290 & 274 & 287 & 103 & 360 & & \\
\hline $\mathrm{Yb}$ & 1.5 & 1.51 & 1.59 & 1.83 & 1.6 & 1.4 & 1.25 & 1.69 & & \\
\hline $\mathrm{Mg}, \%$ & 57 & 66 & 60 & 57 & 59 & 62 & 3 & 35 & 59 & 38 \\
\hline
\end{tabular}

${ }^{1} \mathrm{X} 1, \mathrm{X} 2=$ average composition (total with $\mathrm{BaO}$ ) of pseudoleucitic rocks and fergusites $(n 1=14, n 2=17) ; 5 \mathrm{Gl}=$ average composition of five homogeneous glass inclusions in cpx.

Sources: Dmitriyev, 1976; Arnaud et al., 1992; Sobel, 1995.

occurs north of the southern Mongolian area, in western Transbaikalia (Burkal and Vitim areas, Fig. 12).

The mantle magmatism is believed to have developed continuously, from the Late Jurassic to the Holocene (Yarmolyuk et al., 1995). However, the separate occurrence of Jurassic-Early Cretaceous volcanic troughs and the different compositions and structures of volcanics support the idea that Cenozoic magmatism in these areas-as in other regions such as the Tien Shan, Tibet, and Dariganga-was an independent event unrelated to previous magmatism. For instance, a series of Late Jurassic-Early Cretaceous rift troughs separates the Dariganga and western Transbaikalia areas, as well as the Hangai and southern Mongolian areas.
Jurassic-Early Cretaceous volcanics alternate with rift sediments and are represented mostly as a bimodal rift-type series. Cenozoic alkaline and subalkaline basalts occur preferentially as plateau basalts or as stratovolcanoes (KhamarDaban), valley lava flows, and slag cones (Bartoi River, Oka River, etc.) and may be associated locally with "pull-apart" basins (the Tunka depression, for example). As shown in Table 5 (from Yarmolyuk et al., 1995), Upper Jurassic-Lower Cretaceous basalts are characteristic in composition: of a total of 586 analyses of those volcanics, over one-third relate to alkaline-salic rocks such as trachyte, trachytelatite, and trachyrhyolite; of a total of 925 analyses of Upper Cretaceous-Cenozoic rocks, only 11 analyses $(12 \%)$ are trachytes. 
TABLE 4. K-Ar Ages of Cenozoic Volcanic Rocks from Tibet and SE Pamir

\begin{tabular}{llll}
\hline Block & Rock & K-Ar ages, Ma & Source \\
\hline Lhasa block & K-rich acidic and basic, volcanics & $15-19$ & Dong, 1985 \\
Lhasa block, Macgiang area & K-rich basic and intermediate & $20-28$ & Coulon et al., 1986 \\
Southeastern Pamir & Ultra-K basic and intermediate & $14-19$ & Dmitriyev, 1976 \\
Gantang block & K-rich acidic and basic & $9-16$ & Dong, 1985 \\
Kunlun block, Tienchuihai & K-rich basic and intermediate & $3.6-6.4$ & Arnaud et al., 1992 \\
Kunlun block & K-rich basic volcanics & $0.5-4.2$ & Dong, 1985 \\
\hline
\end{tabular}
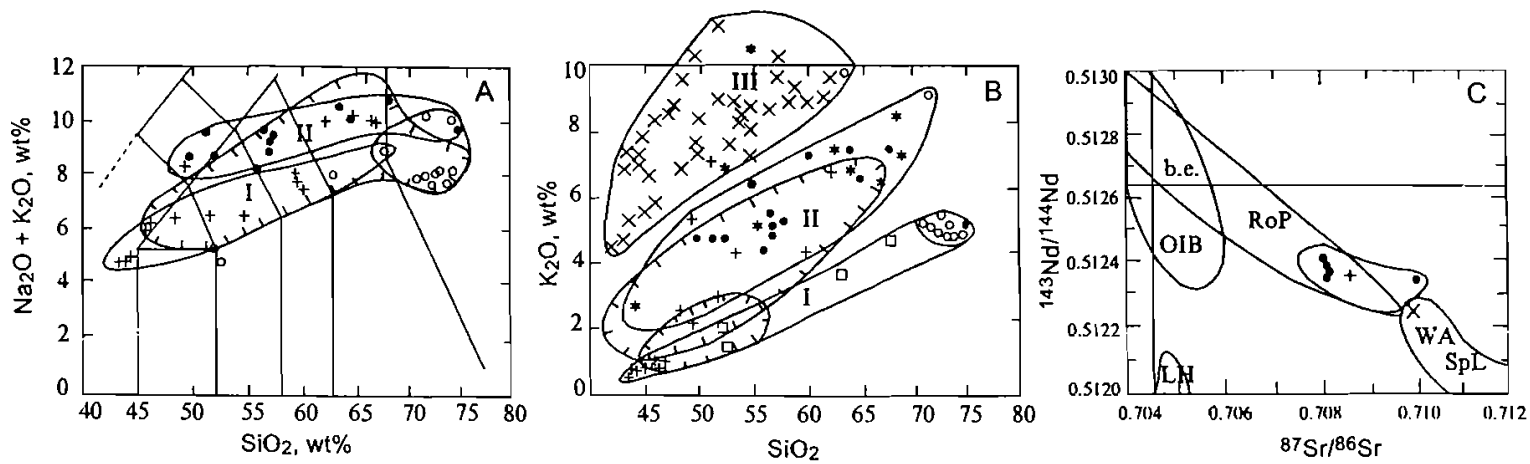

- Lavas sampled and analyzed by Arnaud et al. (1992)

- Rhyolites from eastern Tibet (from McKennan and Walker, 1990)

- Basic and intermediate lavas from the Macqiang series (Coulon et al., 1986)

+ Analyses of Tertiary and Quaternary lavas from northern Tibet (Deng. 1985)

*\} High-K and intermediate series from eastern Pamir (Dmitriev, 1976)

r.

Composition of boninite field, Mongolia and near-Baikal

FIG. 11. Compositional diagrams of Mesozoic-Cenozoic lavas in Central Asia. Abbreviations: OIB = oceanic island basalts; RoP = Roman province lavas; $\mathrm{LH}=$ Leucite Hill; WA = Western Australia; $\mathrm{SpL}=$ Spanish lamproites (after Foley et al., 1987).

Upper Cretaceous-Eocene basalts are dominated by moderate-potassium varieties, with 1.4 to $2.0 \% \mathrm{~K}_{2} \mathrm{O}, 3.4$ to $5.0 \% \mathrm{Na}_{2} \mathrm{O}$, and often low $\mathrm{TiO}_{2}(1.5$ to $2.1 \mathrm{wt} \%)$. In younger basalts, K-rich (2 to $3 \% \mathrm{~K}_{2} \mathrm{O}$, up to $4.85 \%$ in trachyte from the Udokan region) and high-Ti (2.3 to 3.7 $\mathrm{TiO}_{2}$ ) rocks occur more frequently (Table 4). Upper Cretaceous basalts formed as thin fissure flows associated with dikes, sills, stocks, and laccoliths. Toward the end of the stage ( 31 to 42 $\mathrm{Ma})$, slag-bomb volcanoes dominated. Within the southern Mongolian area, there was no migration of basalts of different age, except for late Upper Cretaceous basalts that moved to the east with respect to early Upper Cretaceous and Eocene basalts (Fig. 13).
Northward migration of basalts is, however, pronounced in the middle Oligocene. In the northern Hangai area, upper Miocene-Quaternary basalts are exposed. The time scale of basalt ages (Fig. 14) shows three minima-83 $\mathrm{Ma}$ (middle Late Cretaceous), $45 \mathrm{Ma}$ (sometimes $67 \mathrm{Ma}$, as in the Tien Shan), and 20 to 25 Ma. The maxima are 55 and $75 \mathrm{Ma}$, as in the Tien Shan (Fig. 14). However, the principal minimum coinciding with the most intensive migration of areas of volcanism is 25 to $30 \mathrm{Ma}$, but not 30 to $40 \mathrm{Ma}$ as in the Tien Shan and Pamirs. Nevertheless, in the southern Baikal area, eruptions started at $35 \mathrm{Ma}$. In addition, the range of 28 to $42 \mathrm{Ma}$ is well recorded by $\mathrm{Sm}-\mathrm{Nd}$ mineral isochron datings of mantle 


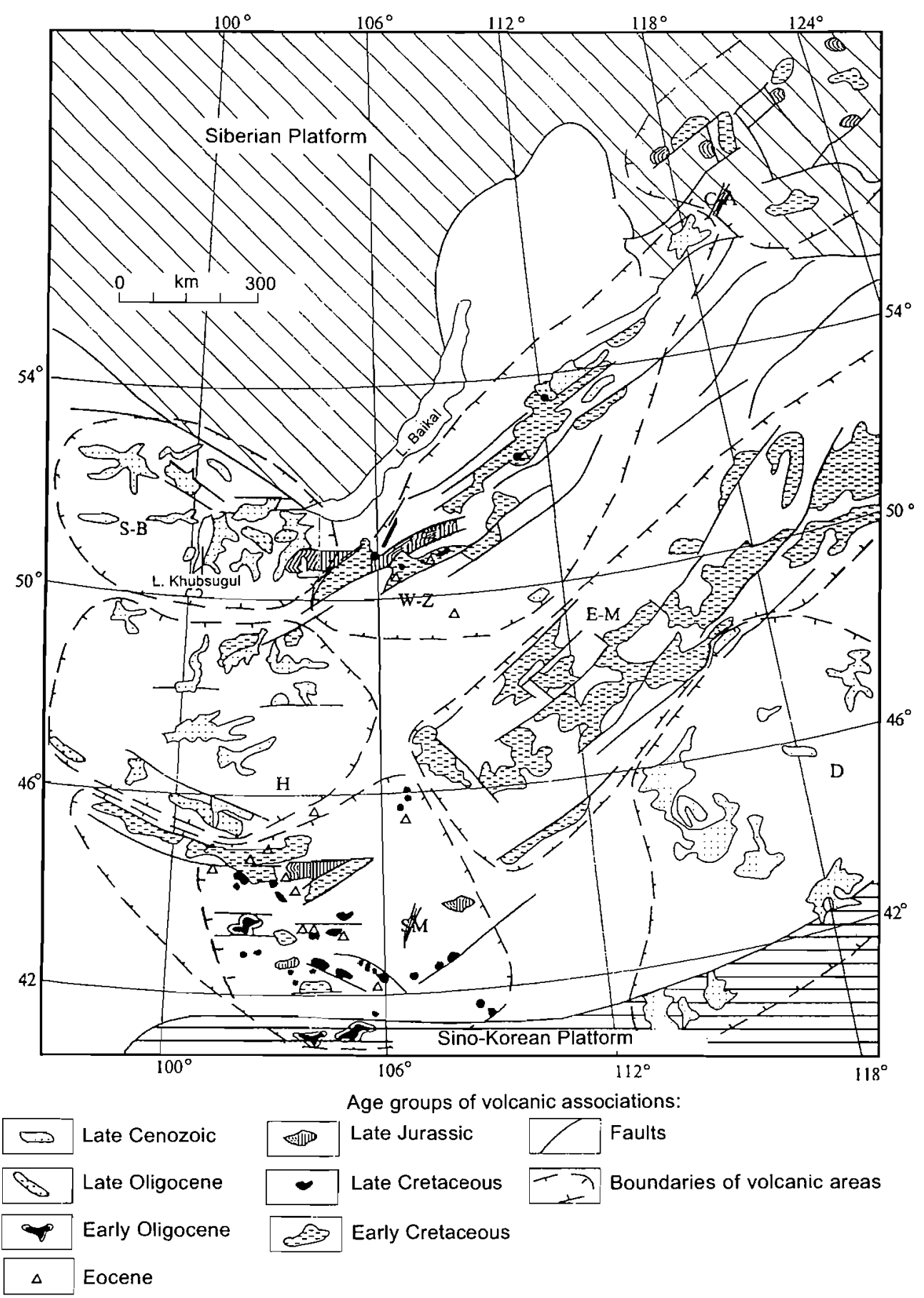

Fig. 12. Location of Upper Mesozoic-Cenozoic intraplate volcanics in Central Asia (modified from Yarmoyluk et al., 1995). Abbreviations: $\mathrm{CA}=$ Central Aldan; W-Z = western Baikal; $\mathrm{S}-\mathrm{B}=$ southern Baikal; $\mathrm{H}=\mathrm{Hangai} ; \mathrm{E}-\mathrm{M}=$ eastern Mongolia; S-M = southern Mongolia; D = Dariganga.

xenoliths. The latter likely indicate a stage of mantle "metasomatism" (Kovalenko and Yarmolyuk, 1990) followed by multiple Late Cenozoic basaltic eruptions. According to other data, that stage corresponds with the initiation of the upwelling of mantle diapirs and with the regeneration of earlier-depleted mantle, ending with basaltic eruptions.

\section{Hangai-Transbaikal}

The Hangai-Transbaikal field of Late Cenozoic volcanism extends to the south, east, 
Table 5. Average Composition of Cenozoic Volcanics of Mongolia and the Baikal Regions

\begin{tabular}{|c|c|c|c|c|c|c|c|c|c|c|c|c|c|c|}
\hline Age interval & Area & Rocks & $N$ & $\mathrm{SiO}_{2}$ & $\mathrm{TiO}_{2}$ & $\mathrm{Al}_{2} \mathrm{O}_{3}$ & $\mathrm{Fe}_{2} \mathrm{O}_{3}$ & $\mathrm{FeO}$ & $\mathrm{MnO}$ & $\mathrm{MgO}$ & $\mathrm{CaO}$ & $\mathrm{Na}_{2} \mathrm{O}$ & $\mathrm{K}_{2} \mathrm{O}$ & $\mathrm{P}_{2} \mathrm{O}_{5}$ \\
\hline \multirow[t]{2}{*}{ Late Cretaceous } & Hangai & $\mathrm{SAB}$ & 27 & 50.89 & 2.18 & 15.55 & 5.91 & 4.56 & 0.14 & 5.69 & 8.38 & 4.12 & 2.07 & 0.51 \\
\hline & Hangai & $\mathrm{B}$ & 6 & 44.74 & 2.15 & 14.25 & 6.08 & 6.74 & 0.24 & 7.55 & 10.61 & 5.03 & 1.72 & 0.99 \\
\hline \multirow[t]{3}{*}{ Eocene } & Hangai & $\mathrm{SAB}$ & 5 & 49.58 & 2.16 & 15.42 & 3.95 & 6.94 & 0.14 & 6.51 & 9.08 & 4.18 & 1.57 & 0.47 \\
\hline & Western Baikal & $\mathrm{TAB}$ & 20 & 54.69 & 1.55 & 17.76 & 8.38 & 2.49 & 0.15 & 2.15 & 7.46 & 3.87 & 1.4 & 0.5 \\
\hline & Western Baikal & $\mathrm{AB}$ & 11 & 45.72 & 2.82 & 13.03 & 3.9 & 8.99 & 0.17 & 9.91 & 9.68 & 3.37 & 1.6 & 0.81 \\
\hline \multirow[t]{2}{*}{ Early Oligocene } & Hangai & SAB & 21 & 51.39 & 2.57 & 14.87 & 3.48 & 6.41 & 0.12 & 6.23 & 6.87 & 4.29 & 3.04 & 0.71 \\
\hline & Western Baikal & $\mathrm{AB}$ & 16 & 46.26 & 2.81 & 13.7 & 4.39 & 8.14 & 0.17 & 8.46 & 9.75 & 3.77 & 1.61 & 0.94 \\
\hline \multirow[t]{2}{*}{ Late Oligocene } & Hangai & $\mathrm{AB}$ & 37 & 47.85 & 2.61 & 14.16 & 4.48 & 6.6 & 0.15 & 7.69 & 9.31 & 3.82 & 2.47 & 0.86 \\
\hline & Southern Baikal & SAB & 15 & 50.58 & 2.7 & 14.41 & 4.16 & 7.05 & 0.13 & 6.75 & 6.94 & 3.43 & 3.11 & 0.74 \\
\hline \multirow[t]{2}{*}{ Early Miocene } & Hangai & $\mathrm{AB}$ & 52 & 49.62 & 2.56 & 14.45 & 4.03 & 6.32 & 0.14 & 7.11 & 8.18 & 4.18 & 2.54 & 0.87 \\
\hline & Southern Baikal & $\mathrm{SAB}$ & 118 & 48.6 & 2.35 & 15.12 & 3.32 & 8.11 & 0.16 & 8.15 & 8.3 & 3.47 & 1.78 & 0.64 \\
\hline \multirow[t]{5}{*}{ Late Miocene } & Hangai & $\mathrm{SAB}$ & 13 & 49.27 & 2.19 & 15.51 & 3.35 & 7.18 & 0.15 & 7.81 & 8.03 & 3.81 & 2.08 & 0.62 \\
\hline & Southern Baikal & $\mathrm{SAB}$ & 146 & 49.04 & 2.38 & 14.92 & 3.59 & 7.91 & 0.15 & 7.78 & 8.01 & 3.63 & 1.96 & 0.63 \\
\hline & Vitim & $\mathrm{SAB}$ & 19 & 49.45 & 2.21 & 14.48 & 3.98 & 7.42 & 0.15 & 8.21 & 8.61 & 3.48 & 1.58 & 0.43 \\
\hline & Udokan & SAB & 21 & 47.98 & 2.29 & 15.96 & 4.94 & 7.15 & 0.17 & 7.13 & 8.39 & 3.88 & 1.56 & 0.54 \\
\hline & Udokan & $\mathrm{B}$ & 5 & 43.21 & 2.94 & 14.28 & 4.32 & 8.4 & 0.19 & 9.44 & 9.37 & 4.5 & 2.22 & 0.82 \\
\hline \multirow[t]{6}{*}{ Pliocene } & Hangai & $\mathrm{AB}$ & 67 & 51 & 2.47 & 15.33 & 2.59 & 7.38 & 0.13 & 6.41 & 7.66 & 4.1 & 2.31 & 0.62 \\
\hline & Southern Baikal & SAB & 100 & 48.21 & 2.48 & 14.96 & 3.07 & 8.24 & 0.16 & 8.01 & 8.65 & 3.76 & 1.85 & 0.61 \\
\hline & Vitim & $\mathrm{AB}$ & 7 & 45.46 & 2.82 & 13.67 & 4.02 & 8.5 & 0.16 & 9.86 & 8.87 & 3.7 & 2.32 & 0.63 \\
\hline & Udokan & $\mathrm{AB}$ & 15 & 46.6 & 2.51 & 15.1 & 5.41 & 6.8 & 0.18 & 8.58 & 8.64 & 3.77 & 1.88 & 0.53 \\
\hline & Udokan & $\mathrm{B}$ & 10 & 42.49 & 3.02 & 11.79 & 5.83 & 6.49 & 0.17 & 12.48 & 11.2 & 3.25 & 2.51 & 0.8 \\
\hline & Udokan & $\mathrm{T}$ & 11 & 58.01 & 0.91 & 18.52 & 3.14 & 3.68 & 0.17 & 1.29 & 3.08 & 5.98 & 4.85 & 0.35 \\
\hline Pleistocene- & Hangai & $\mathrm{AB}$ & 79 & 51.21 & 2.44 & 15.31 & 2.51 & 6.95 & 0.13 & 6.23 & 7.5 & 4.47 & 2.56 & 0.69 \\
\hline Holocene & Southern Baikal & $\mathrm{AB}$ & 40 & 47.51 & 2.31 & 15.72 & 4.33 & 7.55 & 0.16 & 7.41 & 7.94 & 4.25 & 2.09 & 0.73 \\
\hline
\end{tabular}

Abbreviations: $\mathrm{AB}=$ alkaline basalt $; \mathrm{SAB}=$ sub-alkaline basalt $; \mathrm{B}=$ basanite $; \mathrm{T}=$ trachyte $; \mathrm{TAB}=$ trachyandesite-basalt. 


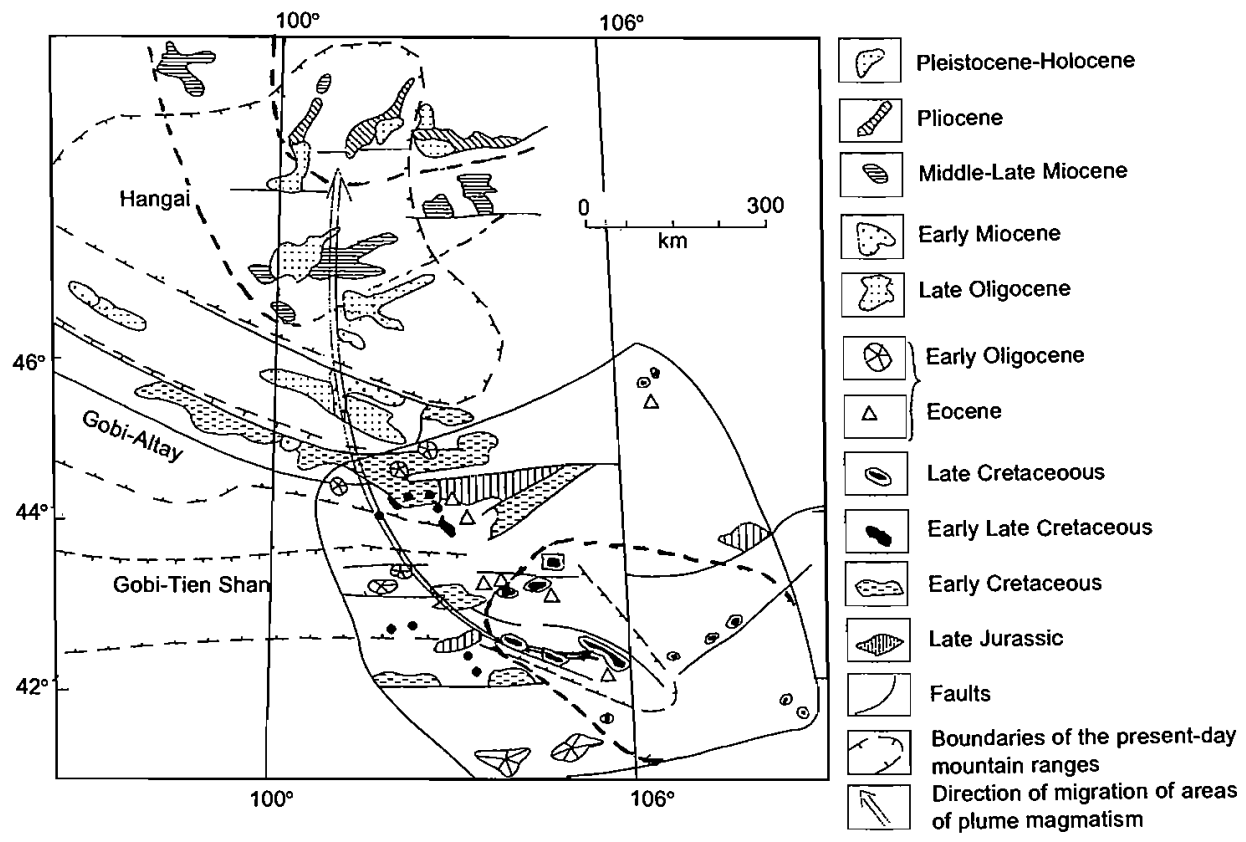

FIG. 13. Distribution of southern Hangai volcanic associations of different ages (modified from Yarmolyuk et al., 1995).

and southwest of Lake Baikal and is defined by several independent subfields (Fig. 12) Hangai (near the Hangai Upland), southern Baikal (Khamar-Daban Ridge, southwestern part of the East Sayan), and the Tunka and Khubsugul depressions. Three small fields (Burkal, Vitim, and Udokan) are located to the northeast, in the western Transbaikal basaltic area of Late Cretaceous-Eocene age. Their origin possibly is the result of northeastward migration within the western Transbaikal area, whereas the origin of the Hangai and southern Baikal fields may be the result of the NNW migration of the southern Mongolian volcanic area. These clockwise displacements (Fig. 8) likely reflect the counterclockwise rotation of the Asian plate over two (or three?) local mantle plumes belonging to the Mongolian superplume (Windley and Allen, 1993). The displacement was most notable in the Oligocene and was altered by the clockwise rotation of the Amur plate in the late Miocene (Zonenshain and Savostin, 1979).

The migration of smaller fields during the late Oligocene-Holocene is variable. The Hangai area illustrates a successive northward migration of the center of magmatism; a late Oligocene-early Miocene area is located in the lake valley between the Hangai Upland and Gobi
Altay, whereas middle-late Miocene to Holocene areas are located to the north, within the Hangai Upland and nearby. Inside the southern Baikal area, a small Oligocene-early Miocene field extends radially up to maximal PlioceneHolocene age during its northwestward migration (Figs. 12 and 13). A local concentric zonation with NE displacement is recorded in the Vitim Plateau (Ashchepkov, 1991; Dobretsov and Ashchepkov, 1991).

In the southern Baikal area, eruptions began in the Khamar-Daban Range at 24 to $34 \mathrm{Ma}$, with two maxima at 15 to 20 and 7 to $12 \mathrm{Ma}$, in the Miocene. Valley basaltic flows formed in the early Pliocene (2 to $6 \mathrm{Ma}$ ) and were completed by slag cones on the flanks of the primary uplift. During all stages, subalkaline olivine basalts dominated, but basanites became more important in the Pleistocene and Holocene.

In the Hangai area, the same volcanic phases-0 to $2,2.5$ to 6,8 to 14,16 to 20 , and 24 to $30 \mathrm{Ma}-$ can be recognized. The $8-$ to $14-\mathrm{Ma}$ phase is the most important one, with basalts reaching $600 \mathrm{~m}$ thick. A large plateau lava developed in the center of the Hangai area, and valley basalts with slag cones formed in the northeastern part of the area. In the Vitim Plateau, an early Miocene phase is recognized at 16 to $21 \mathrm{Ma}$ (e.g., Ashchepkov, 1991), but the 

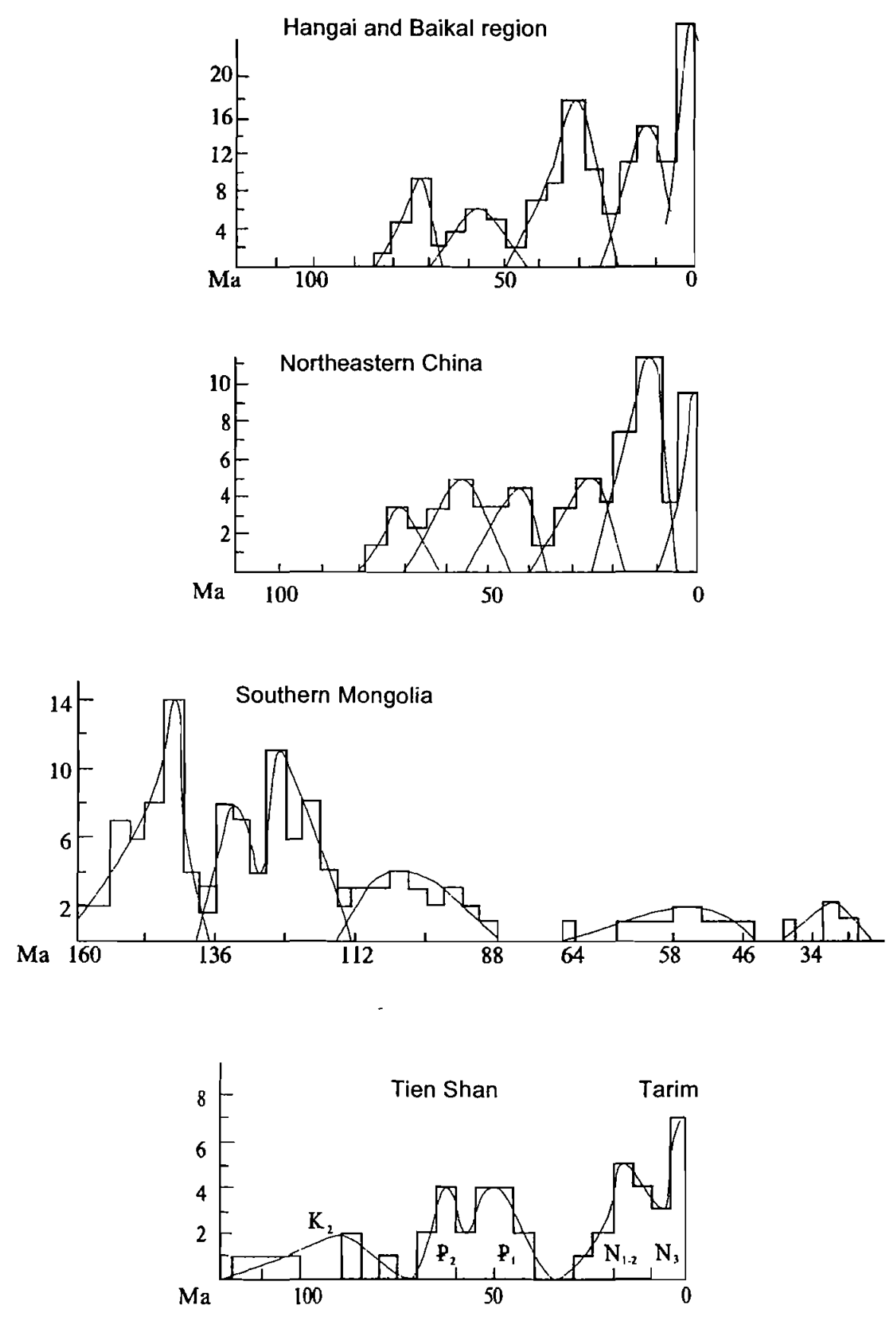

Fic. 14. Age histograms for Late Mesozoic-Early Cenozoic magmatic rocks in the Tien Shan, Tarim Basin, Mongolia, northeastern China, Hangai Mountains, and Baikal region.

main eruption phase occurred in the middlelate Miocene ( 9 to $14 \mathrm{Ma}$ ), with plateau basalts exceeding $200 \mathrm{~m}$ in thickness. Volcanic activity continued in the Pliocene, with valley basalts and basanites (2 to $5 \mathrm{Ma}$ ) and later slag cones with basanites and limburgites.

The most K-rich leucitic basalts and basanites, mainly of Holocene age, are present in the Hangai region. Similar but more nearly unique are the rocks of the Udokan Plateau, with an early volcanic phase at 9 to $14 \mathrm{Ma}$ and major eruptions in the Pliocene (2.7 to $6 \mathrm{Ma}$ ). Later volcanics occur as volcanoes consisting primarily of alkaline rocks such as K-basanite, mugearite, trachyte, and melaleucitite. All the rocks are rich in potassium and similar to rocks from Tibet. Thus, the basalt alkalinity and K-content in the Hangai-Transbaikal areas 
TABLE 6. Composition of Cenozoic Volcanics from the Dariganga Area

\begin{tabular}{|c|c|c|c|c|c|c|c|c|c|}
\hline \multirow[t]{2}{*}{ Components } & & & \multirow{2}{*}{$\begin{array}{c}\text { Dariganga } \\
3\end{array}$} & \multirow[b]{2}{*}{4} & \multirow[b]{2}{*}{5} & \multirow[b]{2}{*}{6} & \multirow{2}{*}{$\begin{array}{c}\text { Khalhin-gol } \\
7\end{array}$} & \multirow[b]{2}{*}{8} & \multirow{2}{*}{$\begin{array}{c}\text { North } \\
\text { China } \\
9\end{array}$} \\
\hline & 1 & 2 & & & & & & & \\
\hline $\mathrm{SiO}_{2}$ & 49.56 & 48.80 & 45.71 & 46.28 & 44.97 & 47.50 & 56.50 & 57.15 & 47.09 \\
\hline $\mathrm{TiO}_{2}$ & 2.50 & 2.52 & 2.76 & 2.77 & 2.51 & 1.94 & 1.54 & 1.18 & 2.36 \\
\hline $\mathrm{Al}_{2} \mathrm{O}_{3}$ & 13.42 & 13.81 & 13.11 & 12.70 & 10.61 & 13.35 & 12.20 & 13.89 & 14.87 \\
\hline $\mathrm{Fe}_{2} \mathrm{O}_{3}$ & 4.20 & 2.98 & 3.39 & 5.05 & 6.02 & 6.10 & 3.58 & 1.79 & 3.62 \\
\hline $\mathrm{FeO}$ & 8.05 & 8.26 & 8.34 & 7.22 & 6.60 & 5.68 & 6.61 & 7.79 & 7.57 \\
\hline $\mathrm{MnO}$ & 0.15 & 0.20 & 0.21 & 0.22 & 0.18 & 0.24 & 0.18 & 0.19 & 0.18 \\
\hline $\mathrm{MgO}$ & 7.80 & 7.81 & 8.98 & 8.58 & 10.70 & 9.30 & 5.83 & 5.48 & 7.32 \\
\hline $\mathrm{CaO}$ & 8.99 & 8.73 & 10.63 & 10.34 & 9.88 & 9.25 & 5.58 & 8.01 & 8.88 \\
\hline $\mathrm{Na}_{2} \mathrm{O}$ & 3.52 & 3.35 & 3.58 & 3.70 & 3.45 & 3.95 & 4.00 & 3.56 & 3.49 \\
\hline $\mathrm{K}_{2} \mathrm{O}$ & 1.32 & 1.46 & 1.83 & 1.55 & 1.47 & 1.43 & 2.77 & 0.49 & 2.29 \\
\hline $\mathrm{P}_{2} \mathrm{O}_{5}(\mathrm{LOI})^{\prime}$ & 0.49 & $(0.89)$ & $(0.86)$ & (1.86) & $(2.32)$ & $(1.52)$ & (1.11) & $(0.08)$ & (1.53) \\
\hline Total & 100.00 & 99.11 & 99.40 & 100.2 & 98.71 & 100.26 & 99.80 & 99.61 & 99.20 \\
\hline$N$ & 15 & 14 & 7 & 7 & 5 & 2 & 3 & 4 & 12 \\
\hline $\mathrm{Mg}^{\prime}$ & 58.0 & 58.8 & 62.0 & 10 & 67.1 & 74.5 & 62.7 & 54.2 & 58.4 \\
\hline $\mathrm{Zr}$ & - & 340 & 660 & 61.8 & 400 & - & - & 90 & - \\
\hline $\mathrm{Nb}$ & - & 145 & 190 & 300 & 125 & - & - & - & - \\
\hline $\mathrm{Li}$ & - & 10 & 10 & 90 & 9 & - & - & 4 & - \\
\hline $\mathrm{Rb}$ & - & 24 & 28 & 9 & 22 & - & - & 5 & - \\
\hline $\mathrm{Ca}$ & - & 4.5 & 10 & 28 & 3 & - & - & 1 & - \\
\hline $\mathrm{Ni}$ & - & 160 & 205 & 2.5 & 240 & - & - & 120 & - \\
\hline Co & - & 60 & 60 & 220 & 65 & - & - & 50 & - \\
\hline$N$ & - & 13 & 7 & 10 & 3 & - & - & 1 & - \\
\hline
\end{tabular}

$\mathrm{LOI}=$ loss on ignition.

Source: After Kepezhinskas, 1979.

increase toward the end of the volcanic cycle, and are pronounced at the periphery of the volcanic area, particularly in the Udokan field.

Despite the scattering of Cenozoic volcanic outcrops, they are located within the general area of the Mongolian superplume, and they are detected by the increased heat flow and decreased lithosphere thickness (Windley and Allen, 1993). More specifically, they occur within the western part of an area of anomalous mantle having a depth of less than $100 \mathrm{~km}$ (Zorin et al., 1988) (Fig. 8). The eastern part of this area corresponds to the Dariganga area of Late Cenozoic mantle magmatism.

\section{Dariganga and Khingan areas}

The Dariganga and Khingan areas are defined by a chain of vast lava fields extending from the Dariganga Plateau in southeastern Mongolia to the Khingan Range, west and northwest of Bohai Bay. From available data, the formation of the youngest lava plateaus began in the early
Miocene (23 to $25 \mathrm{Ma}$ ) in northeastern China (Fan and Hooper, 1991), and in the middle Miocene ( 8 to $15 \mathrm{Ma}$ ) in the Dariganga Plateau (Yarmolyuk et al., 1995). The major volume of volcanics erupted in the Pliocene (at 3 to $5 \mathrm{Ma}$ ) and formed a lava plateau of more than 14,000 $\mathrm{km}^{2}$ and $100-\mathrm{m}$ mean thickness. In the Pleistocene-Holocene, linear zones of lava and slag cones formed over the entire plateau.

Rock compositions correspond to subalkaline and alkaline ol-basalt, and to a lesser extent to nepheline basanite, tephrite, and hawaiite (Table 6). Kepezhinskas (1979) emphasized that the Dariganga Plateau rocks belong to the sodium series, unlike the previous areas of potassium series. They differ in their bulk compositions, especially in terms of $\mathrm{Na} / \mathrm{K}$ ratios (Tables 5 and 6; Fig. 10), and in the composition of megacrysts and porphyric crystals from lavas and diatremes. In the Dariganga sodic series, megacryst assemblages include clinopyroxene and anorthoclase; in the Hangai- 
TABLE 7. Tertiary Paleomagnetism and Crustal Shortening of the Qinghai-Tibet Plateau

\begin{tabular}{|c|c|c|c|c|c|c|}
\hline Terrane & Age & Paleolatitude, $\mathrm{D}^{\circ}$ & $\begin{array}{l}\text { Modern } \\
\text { latitude, } \mathrm{D}_{1}^{\circ}\end{array}$ & $\begin{array}{c}\text { Northward } \\
\text { displacement in } \\
\text { latitude and } \mathrm{km} \text {, } \\
\left(\mathrm{D}_{1}^{\circ}-\mathrm{D}^{\circ}\right) \times 110\end{array}$ & $\begin{array}{c}\text { Distance } \\
\text { between } \\
\text { terranes, km }\end{array}$ & $\begin{array}{l}\text { Shortening of crust, } \\
\mathrm{km}\end{array}$ \\
\hline Himalaya & Tertiary & $\begin{array}{l}4.5^{\circ} \mathrm{N} \\
\left(2.5^{\circ}-5^{\circ}, 4.6^{\circ} \mathrm{N}\right)\end{array}$ & $28.5^{\circ} \mathrm{N}$ & $\begin{array}{l}24^{\circ} \\
2664\end{array}$ & & \\
\hline Gangdise & Tertiary & $\begin{array}{l}12^{\circ} \mathrm{N} \\
(10-13.8)\end{array}$ & $30^{\circ} \mathrm{N}$ & $\begin{array}{l}18^{\circ} \\
1980\end{array}$ & 130 & $\begin{array}{l}2664-(1980+130) \\
=554\end{array}$ \\
\hline Qiangtang & Tertiary & $\begin{array}{l}27.5^{\circ} \mathrm{N} \\
(25.4-29.5)\end{array}$ & $32.5^{\circ} \mathrm{N}$ & $\begin{array}{l}5^{\circ} \\
550\end{array}$ & 440 & $\begin{array}{l}1980-(550+440) \\
=990\end{array}$ \\
\hline Qaidam & Tertiary & $\begin{array}{l}37^{\circ} \mathrm{N} \\
\left(34^{\circ}-40^{\circ}\right)\end{array}$ & $38^{\circ} \mathrm{N}$ & $\begin{array}{l}1^{\circ} \\
110\end{array}$ & 480 & $\begin{array}{l}550-(110+480)= \\
-40\end{array}$ \\
\hline
\end{tabular}

area potassium series, megacrysts of sanidine and phlogopite (or titan-augite) are associated with groundmass leucite or orthoclase (Kepezhinskas, 1979).

A field of alkaline basalts and trachyandesite near the Halhingol River also can be related to the Dariganga area. Nepheline basanites, similar to those of Dariganga, plus trachyandesites and tholeiitic andesites (Table 6) that occur there represent deep-seated differentiated varieties of alkaline sodium basaltoids. Other volcanic fields, differing in the composition of lavas, also included in the Dariganga province in the territory of China, are the region of Veiganga and Dalay-Nor Lake, as well as the site of Mergen (Kepezhinskas, 1979; Fan and Hooper, 1991). In the former region there is a differentiated series from basanite and alkaline basalt to trachyte and trachyliparite. In the Mergen area, the leucitic alkaline basaltoids are abundantly exposed. The distribution and composition of Cenozoic basalts in the Dariganga and Khingan field were not studied in detail; however, a general tendency for volcanic-area migration to the SSW during the Cenozoic is obvious.

\section{Geodynamics and Cenozoic Tectonics of the Southeastern Eurasian Plate}

The geodynamic reconstructions presented here are based on a series of mechanisms and assumptions concerning the Cenozoic tectonics of the Eurasian plate. The generally accepted major mechanism is the deformation induced by the India-Eurasia convergence and collision.
We propose that this deformation propagated away from the Himalayan orogenic zone by successive interaction of blocks (the domino principle). Deformation consisted mainly of thrusting, lateral translation, rifting, and block rotation. In addition to this classical mechanism of "passive" reaction to the "indenter" effect of India, it is suggested that the "active" effects of mantle plumes also are important. Partial melting related to mantle plumes reduces the viscosity of the base of the lithospheric plate. This favors rotation of microplates underlain by the mantle plume. For the other plates, crustal shortening and thinning will be dominant. Moreover, migration of plume-related volcanism with time within the lithospheric plates provides evidence for plate movement over supposedly fixed mantle plumes.

Migration of volcanic activity over time provides evidence for northwestward migration and/or rotation of the Tien Shan, Tarim, and Tibetan microplates in the southeastern part of the Eurasian continent. Rotation and migration also are supported by paleomagnetic data for the Tertiary deposits of western China (e.g., Xuebing et al., 1990; Yaoxiu et al., 1990) and of the Kyrgyz Tien Shan (Thomas et al., 1993). The paleomagnetic data for China are summarized in Table 7 (Xiao and Li, 1995).

According to the paleomagnetic data, Tertiary deposits of the Qiangtang, Gangdise, and Himalaya terranes experienced the impact of the Indian plate and migrated northwestward. The amplitude of displacement of the microplates increases with proximity to the Indian 
plate: the Qaidam basin $=110 \mathrm{~km}$; the Qiangtang terrane $=550 \mathrm{~km}$; the Gangdise terrane $=1980 \mathrm{~km}$; and the Himalayan terrane $=$ $2600 \mathrm{~km}$. The rotation of the southeastern Eurasian plate adequately explains the paleomagnetic data on the Tertiary deposits of the Issyk-Kul' and Fergana depressions in the Kyrgyz Tien Shan (Thomas, 1994). The same data also suggest that, since the Paleocene, the Tien Shan migrated $2000 \mathrm{~km}$ southward, without significant rotation. This conclusion is based on the interpretation of the low magnetic inclination found in the studied samples. However, such an important migration is difficult to accept, since it would cause important shortening between the Tien Shan and Kazakhstan plates. Effectively, Kazakhstan together with Siberia remained in a relatively stable position throughout the entire Cenozoic. Thomas et al. (1993) suggested that there might be some problems in the paleomagnetic data.

This possible northwestward translation of the Tien Shan may explain the migration of volcanic activity from the Tien Shan to Tibet between 40 and $28 \mathrm{Ma}$, but only if one assumes that volcanism occurring in the Tien Shan and Tibet originated from the same fixed mantle plume. Taking into account that between 40 and $28 \mathrm{Ma}$, the field of plume magmatism transited from the Tien Shan to Tibet, the counterclockwise rotation of the Asian plate is supported and confirmed by paleomagnetic data for the Qaidan basin. The latter confirm a weak drift of central China in the Tertiary. Therefore, the Tien Shan block moved north along the TalasFergana and Junggar strike-slip faults, while the Tarim and Tibet blocks underwent rotation.

According to data on paleomagnetism, sedimentology, tectonic history, stratigraphic paleontology, magmatism, metamorphism, and ophiolites, summarized by Xiao and Li (1995), the neo-Tethys oceanic basin closed in the Late Cretaceous-early Eocene, and India collided with Eurasia; since then (about 65 to $50 \mathrm{Ma}$ ), the Qinghai-Tibetan Plateau started to uplift as a consequence of crustal thickening and shortening.

The rate of northward drift of India after its collision with Eurasia was 16 to $17 \mathrm{~cm}$ per year at 65 to $50 \mathrm{Ma}$ (early Paleogene), $10 \mathrm{~cm}$ per year in the Oligocene-Miocene, and 2 to $10 \mathrm{~cm}$ per year in the late Pliocene (Patriat and Achache, 1984; Molnar et al., 1987; Xuebin et al., 1990;
Yaoxiu et al., 1990; Klootwijk et al., 1992). The accepted closure rate of Eurasia in front of the India plate during the Pliocene is: 5 to $6 \mathrm{~cm} / \mathrm{a}$, with $5 \mathrm{~mm} / \mathrm{a}$ absorbed by reverse faults or thrusts in the Himalaya terrane; $15 \mathrm{~mm} / \mathrm{a}$ by the strike-slip faults in the Gangdise terrane; 12 $\mathrm{mm} / \mathrm{a}$ by the strike-slip faults in the Qiangtang terrane; $8 \mathrm{~mm} / \mathrm{a}$ by the Red River dextral strike-slip in the Yunnan block; about $11 \mathrm{~mm} / \mathrm{a}$ by the Altun, Kunlun, and Qilian fault systems; and about $3-5 \mathrm{~mm} / \mathrm{a}$ by the Tien Shan fault system.

According to paleomagnetic data (Achache et al., 1984), the Indian craton, after the initial collision, moved $2000 \mathrm{~km}$ to the north. The Indian plate has been thrust under Tibet for the same distance. In the Eocene, most of the Tibetan block rotated, as suggested by paleomagnetic data and by the migration of plume magmatism. Therefore, in the Eocene, the convergence of the Indian craton and Eurasia was compensated by both rotational movement of its southeastern part and underthrusing beneath the Eurasian plate. This resulted in the most prominent deformations in the Himalayas, and then in the Tibetan Plateau. Early deformations were rather slow, as evidenced by the uplift of the Himalayas and Tibetan Plateau (see below). They may be the consequence of an oblique collision compensated mainly by strikeslip faulting. After the India-Pamir collision (30 to $35 \mathrm{Ma}$ ), deformation propagated to the north and northeast, resulting in the formation of the inner Asian mountain ranges and the splitting of the Asian plate into independent microplates. At that time, the Amur plate came into existence and started to rotate in counterclockwise fashion, producing the Baikal, Central China, and East Mongolian rift systems (Fig. 14).

The rapid uplift (Table 8) of the QinghaiTibetan Plateau since the late Tertiary is fully demonstrated by data on neotectonics, geomorphology, paleontology, and sedimentology (Li, 1988; Pan et al., 1990; Zhang et al., 1992). Uplift proceeded in three major stages (Xiao and $\mathrm{Li}, 1995)$ : (1) a slow uplift stage (0.1-0.4 $\mathrm{mm} / \mathrm{a})$ in the Late Cretaceous-Eocene that resulted mainly from the collision between the Indian plate and the southern terrane of the Qinghai-Tibetan Plateau, as well as from subduction of the former beneath the latter; (2) a 
Table 8. Cenozoic Orogenic Uplift of the Central Asian Belt: Age and Rate

\begin{tabular}{|c|c|c|c|c|}
\hline Region (south to north) & Age of uplift & $\begin{array}{l}\text { Rate of uplift, } \\
\mathrm{mm} / \mathrm{a}\end{array}$ & Method & Source \\
\hline $\begin{array}{l}\text { Qinghai-Tibetan Plateau: } \\
\text { 1. Chomolungma } \\
\text { 2. Himalaya } \\
\text { 3. Lhasa-Gangdise } \\
\text { 4. Kunlun-Karakoram }\end{array}$ & $\begin{array}{c}\text { last } 30 \text { years } \\
0.01 \text { Ma-last few years } \\
0.01 \text { Ma-last few years } \\
\text { last } 30 \text { years }\end{array}$ & $\begin{array}{c}37 \\
10-15 \\
9-10 \\
6-9\end{array}$ & $\begin{array}{l}\text { Geodetic Jeveling } \\
\text { GPS + SLR }\end{array}$ & Xiao and Li, 1995 \\
\hline Western Himalaya & $\begin{array}{c}5-1 \mathrm{Ma} \\
20-10 \mathrm{Ma} \\
40-30 \mathrm{Ma}\end{array}$ & $\begin{array}{c}0.2-0.9 \\
0.92 \\
0.1-0.3\end{array}$ & Fission track & Xiao and Li, 1995 \\
\hline Lhasa-Gangdise & $12-8 \mathrm{Ma}$ & $\begin{array}{c}0.45-0.5 \\
0.25\end{array}$ & Fission track & Xiao and Li, 1995 \\
\hline $\begin{array}{l}\text { Western Tien Shan } \\
\text { Southern Tien Shan }\end{array}$ & $\begin{array}{c}28-12 \mathrm{Ma} \\
23-6 \mathrm{Ma}\end{array}$ & & $\begin{array}{l}\text { Fission track } \\
\text { Crustal subsidence } \\
\text { history }\end{array}$ & $\begin{array}{l}\text { Molnar et al., } 1994 \\
\text { Huafu et al., } 1994\end{array}$ \\
\hline Altay-Sayan area & 3-1 Ma & & $\begin{array}{l}\text { Structure and } \\
\text { geomorphology }\end{array}$ & $\begin{array}{l}\text { Dobretsov et al., 1995, } \\
\text { unpubl. }\end{array}$ \\
\hline
\end{tabular}

medium uplift stage $(0.4-0.5 \mathrm{~mm} / \mathrm{a})$ in the Oligocene-Pliocene that resulted mainly from the compressive deformation within the amalgamated terranes, and rapid rotation of the Tibetan plate; (3) a rapid uplift stage (4-15 $\mathrm{mm} / \mathrm{a}$ ) in the Pleistocene-Holocene that mainly resulted from the underplating of India and isostatic adjustment.

Since the Holocene, the uplift rate has increased rapidly from north to south. Beginning at 35 to $30 \mathrm{Ma}$, after the India-Pamir collision, compressive structures formed within a broad belt between the Indian and Siberian cratons. Tibet ceased to rotate, and for the last $25 \mathrm{Ma}$ its uplifting was accelerated at the expense of underthrusting of the Indian plate. Large-scale thrusts formed during the Miocene in the Pamirs and in the Tien Shan.

In the Baikal area and eastern Mongolia, extensional sedimentary basins formed in a vast extensional stress field in the Late Cenozoic. Where the areas of extensional stress coincided with the presence of mantle plumes, the lithosphere was weakened, leading to the separation of the Amur and Mongolian microplates. At the beginning of the Miocene, the Hangai and western Transbaikalian areas of volcanic activity and the southern Baikal and Dariganga volcanic areas formed as a result of the rotation of the Amur and (to a lesser extent) Mongolian microplates. They significantly changed the regional structure and defined the boundaries of the Amur microplate (Fig. 14). The evolution of the Amur microplate became independent of the compressive structures of the rest of southeastern Eurasia, where deformations induced by the Indian penetration gradually propagated to the north and northwest. In the Miocene, the Amur microplate rotated counterclockwise. Finally, in the Pliocene, the regional compression reached the Amur microplate and caused its southeastward migration (Fig. 1). According to this model, the formation of the Baikal rift is related to the occurrence of extension at the boundary between the Siberian plate and the rotating Amur microplate (Zonenshain and Savostin, 1981; Yarmolyuk et al., 1995). General uplift and formation of high mountains in the Pliocene-Pleistocene are related to the NE migration of compression.

Thus, the evolutionary paths of Cenozoic structures in the Central Asian mountain belt differ for each block or microplate but are interrelated among them. They are related to a gradual northward migration of compression from the collisional margin of the Eurasian plate, according to the "domino" principle, and to the action of mantle plumes on the lithosphere (Table 9). 
TABLE 9. Correlation Scheme of Cenozoic Geodynamic Events in Asia

\begin{tabular}{|c|c|c|c|c|c|c|}
\hline \multirow[t]{2}{*}{$\begin{array}{l}\text { System series geo- } \\
\text { chronometer, } Y(\mathrm{Ma})\end{array}$} & \multirow[t]{2}{*}{$\begin{array}{l}\text { Type of India-Eurasia } \\
\text { plate interaction }\end{array}$} & \multirow[t]{2}{*}{$\begin{array}{l}\text { Velocity of Indian } \\
\text { plate drift, } \mathrm{cm} / \mathrm{y}\end{array}$} & \multicolumn{2}{|c|}{$\begin{array}{l}\text { Periods of manifestation of stable } \\
\text { areas of plume magmatism }\end{array}$} & \multicolumn{2}{|c|}{ Types of deformation } \\
\hline & & & Inner Asia & Amur microplate & Inner Asia & Amur microplate \\
\hline $\begin{array}{l}\text { Holocene } \\
0.01 \\
\text { Pleistocene }\end{array}$ & $\begin{array}{l}\text { Collision with Pamirs } \\
\text { and gradual propaga- } \\
\text { tion of deformation } \\
\text { to the north and } \\
\text { northeast }\end{array}$ & $5-6$ & 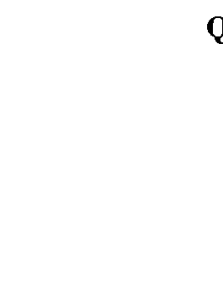 & $\begin{array}{l}\text { rnary } \\
\text { 7-0 Ma } \\
\text { (Dariganga) }\end{array}$ & $\begin{array}{l}\text { In the Altay, strike- } \\
\text { slip faults dominat- } \\
\text { ing, thrusts and rifts } \\
\text { to a lesser extent }\end{array}$ & $\begin{array}{l}\text { Combination of strike- } \\
\text { slip faults, arch uplifts, } \\
\text { and extension zones }\end{array}$ \\
\hline $\begin{array}{l}1.6 \\
\text { Pliocene } \\
5.3 \\
\text { Miocene } \\
23\end{array}$ & & $\begin{array}{r}2-10 \\
10\end{array}$ & $\begin{array}{c}\text { 24- } 12 \mathrm{Ma} \\
\text { (eastern Pamir) } \\
\text { 28-0.5 Ma } \\
\text { (Tibet) }\end{array}$ & $\begin{array}{c}25-0 \mathrm{Ma} \\
\text { (Hangai, Baikal area) }\end{array}$ & $\begin{array}{l}\text { In the Tien Shan, } \\
\text { thrusts and strike-slip } \\
\text { faults; in the Pamirs } \\
\text { and Himalayas, } \\
\text { thrusts and } \\
\text { underthrusts }\end{array}$ & $\begin{array}{l}\text { Extension zones (Baikal } \\
\text { rift and associated } \\
\text { basins) }\end{array}$ \\
\hline $\begin{array}{l}\text { Oligocene } \\
36.5\end{array}$ & Oblique subduction & & 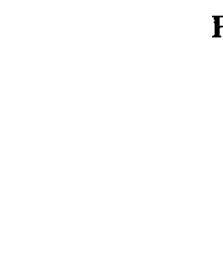 & $\begin{array}{l}\text { gene } \\
\text { 80-30 Ma } \\
\text { (southern Mongolia) }\end{array}$ & $\begin{array}{l}\text { For the Indian plate, } \\
\text { thrusting under } \\
\text { Eurasia, forming the } \\
\text { Qinghai-Tibetan } \\
\text { plateau }\end{array}$ & \\
\hline $\begin{array}{l}\text { Eocene } \\
53 \\
\text { Paleocene } \\
65\end{array}$ & & $16-17$ & $\begin{array}{c}\text { 113-40 Ma } \\
\text { (Tien Shan) } \\
\text { subduction } \\
\text { magmatism, } \\
\text { 120-60 Ma } \\
\text { (southern Tibet, } \\
\text { Pamirs) }\end{array}$ & & & \\
\hline
\end{tabular}



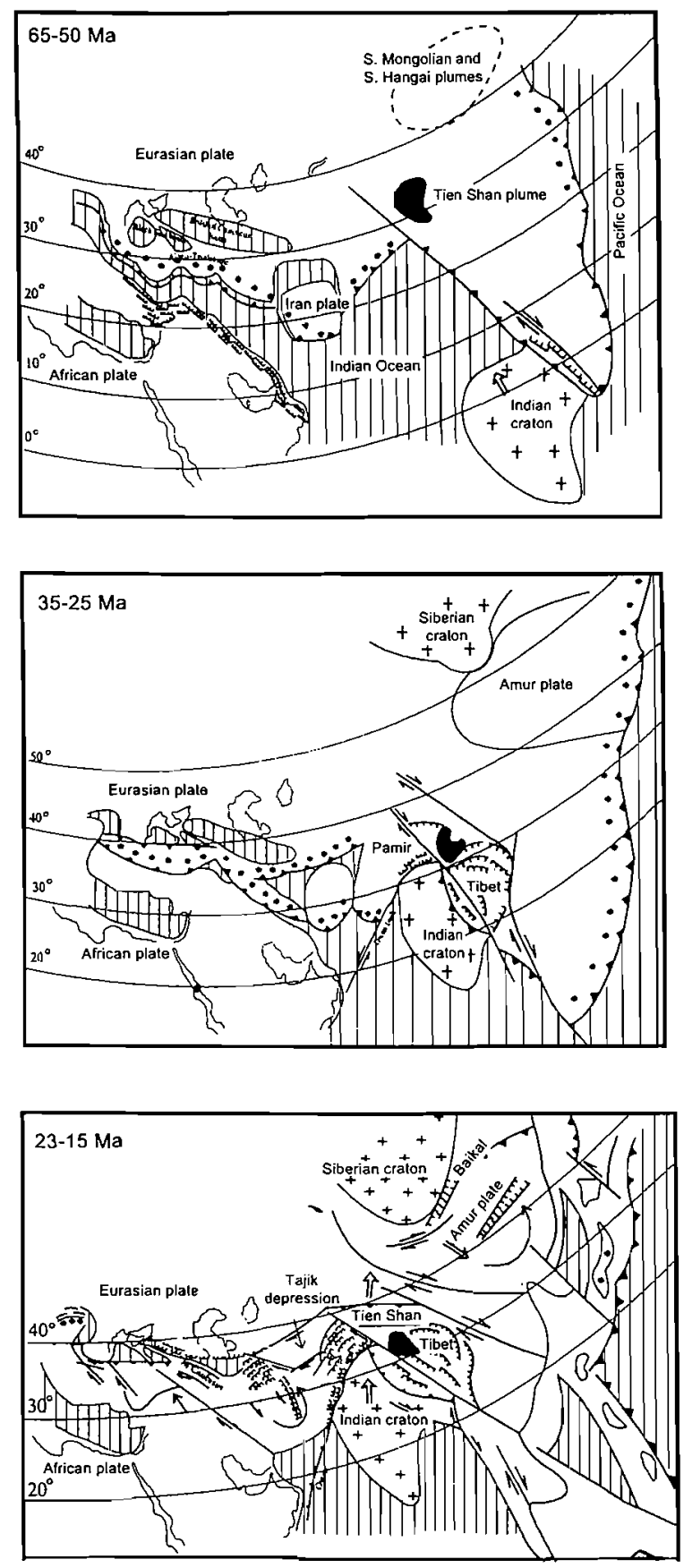

FIG. 15. Palinspastic reconstructions of Central Asian structure formation for the periods 65 to $50 \mathrm{Ma}, 32$ to 25 Ma, and 23 to $15 \mathrm{Ma}$ (compiled from Achache et al., 1984; Zonenshain et al., 1990).

Accordingly, important mechanisms must be added to the commonly accepted model for the "indentation" of the Indian plate (Cobbold et al., 1995; Zonenshain and Savostin, 1979; Cobbold and Davy, 1988): (1) interaction of moving plates with upper mantle material upwelling in extensional zones-in particular, near the mantle hot spots (Amur, Tibetan, and Tien Shan microplates); (2) gradual migration of the intensity of moving plates on the "domino" principle. The latter principle illustrates a chain of interrelated events, especially for the last $30 \mathrm{Ma}$ : (a) underthrusting of the Indian plate, causing the uplift of Tibet (and upper mantle upwelling); (b) thrusting of Tibet and the Tien Shan over the Tarim plate, which evolved into a ramp depression; (c) uplift of the Tien Shan, subsidence of the Junggar basin, and 
thrusting of the Mongolian Altay along its northern margin; (d) uplift and compression of the central Altay and Sayan along the southwestern boundary of the Siberian craton; and (e) subsidence and extension with formation of the Baikal rift zone along the southeastern margin of the Siberian craton.

\section{Conclusions}

A comparison of Mongolia, Baikal, Altay, Tien Shan, Pamir, and Tibet has shown that the main mechanisms for their tectonic evolution, orogeny, and basin sedimentation in Central Asia are similar but changed regularly in time and space, as illustrated in Figure 15. Initially, deformation began at about $60 \mathrm{Ma}$, after the India-Asia collision. The deformational events were preceded by a stage of tectonic stabilization (peneplanation) and formation of upper Cretaceous-lower Paleogene weathering crusts in the Tien Shan, Altay, Baikal area, and Mongolia, and subduction processes in the Himalayas (plus southern Tibet) and Pamirs. Between 60 and $35 \mathrm{Ma}$, high mountains formed in the Himalayas, southern Tibet, and, possibly, the southern Tien Shan. Eocene deposits formed coevally in the near-Himalaya trough, the Tarim and Tajik depressions, and the Fergana basin.

In the second stage (35-0 Ma), mountain building and sedimentary-basin formation occurred in the Qinghai-Tibetan Plateau (20-12 Ma), Tien Shan (18-11 Ma), Junggar (8-5 Ma), Altay, Sayan, and Baikal (3 Ma).

A regular northward rejuvenation of mountains and coarse-clastic intermontane deposits shows that deformations propagated and mountains grew gradually, according to the domino principle: (1) India thrusting under Tibet and the rotation of Tibet (60 to $35 \mathrm{Ma}$ ); (2) subsidence of the Tarim ramp depression, rise of the Tien Shan, and the migration of Tien Shan and Tarim to the northwest along the Junggar and Talas-Fergana strike-slip faults; (3) subsidence of the Junggar plate and counterclockwise rotation of the Mongolian and Amur plates; (4) uplift of the Altay and the Hangai mountains, counterclockwise rotation of the Amur plate, and formation of the Baikal rift. The rotation of the Tibetan and Amur microplates and displacement of their borders were caused by the occur- rence of mantle plumes, whose effects on moving plates are illustrated by the migration of volcanic areas of the Tien Shan, Tibet, southern Mongolia, and Hangai (Figs. 8 and 12). Less thoroughly documented is the migration of other volcanic areas along the Amur plate margin. The early magmatic histories in each area were different, and tectonic processes became synchronous just after the collision of India with the southern Himalaya area $(60 \mathrm{Ma})$ and the Pamirs (35 Ma).

The absence of mantle magmatism in the Altay region indicates that the tectonic activity of this area is not related to mantle plumes, but results from the propagation of tectonic deformation away from the zone of collision, far to the north. In the Altay, Junggar, and Tarim areas, deformation occurred mainly by thrust and strike-slip faulting with block rotations. Sedimentary basins evolved as ramps, halframps, pull-aparts, or extensional grabens. The scenarios suggested here are debatable, but we believe that they better reflect the complex history of the formation of the Central Asian mountain belt than the simple "indenter" model of India into Eurasia.

\section{Acknowledgments}

We thank our colleagues, Prof. J. Klerkx, Drs. K. Theunissen, V. Zykin, A. Kazansky, J.-Ch. Thomas, and Prof. R. Lanza for joint field work and many useful discussions in the framework of the INTAS Project on "Continental Rift Tectonics and Evolution of Sedimentary Basins."

\section{REFERENCES}

Achache, J., Courtillot, V., and Zhou, X. Z., 1984, Paleogeographic and tectonic evolution of southern Tibet since Middle Cretaceous time: New paleomagnetic data and synthesis: Jour. Geophys. Res., v. 89, p. 10311-10339.

Afonichev, N. A., and Vlasov, H. G., eds., 1984, Geological map of Kazakhstan and Central Asia: Lenningrad, USSR Min. of Geology (in Russian).

Aplonov, S. V., 1987, Geodynamics of the Early Mesozoic $\mathrm{Ob}$ paleoocean: Moscow, USSR Acad. Sci., Inst. of Oceanology, 98 p. (in Russian).

Arnaud, N. O., Vidal, Ph., Tapponnier, P., Matte, Ph., and Deng, W. M., 1992, The high $\mathrm{K}_{2} \mathrm{O}$ volcanism of northwestern Tibet: Geochemistry and tectonic 
implications: Earth Planet. Sci. Lett., v. 111, p. 35l-367.

Ashchepkov, I. V., 1991, Deep-seated inclusions of the Baikal Rift: Novosibirsk, Nauka Press, 160 p. (in Russian).

Avouac, J. P., Tapponnier, P., Bai, M., You, H., and Wang, G., 1993, Active thrusting and folding along the northern Tien Shan, and Late Cenozoic rotation of the Tarim relative to the Junggar and Kazakhstan: Jour. Geophys. Res., v. 98, p. 6755-6804.

Bakirov, A. B., and Dobretsov, N. L., 1978, Metamorphic complexes in Middle Asia: Frunze, Ilim Publ., 124 p. (in Russian).

Baljinnyam, O., Bayasgalan, L. A., Borisov, B. A., Cistemas, A., Dem'yanovich, M. G., Ganbaator, L., Kochetkov, V. M., Kurushin, R. A., Molnar, P., Philip, H., and Vashchilov, Yu. Ya., 1993, Ruptures of major earthquakes and active deformation in Mongolia and its surroundings: Geol. Soc. Amer. Memoir 181, 62 p.

Basharina, N. P., 1975, Mesozoic depressions in the Altay-Sayan and Kazakhstan folded areas: Novosibirsk, Nauka Press, 124 p. (in Russian).

Bazhenov, M. L., and Burtman, V. S., 1986, Tectonics and paleomagnetism of structural arcs of the PamirPunjab syntaxis: Jour. Geodyn., v. 5, p. 383-396.

Berzin, N. A., Coleman, R. G., and Dobretsov, N. L., 1994, Geodynamic map of the western part of the Paleoasian ocean: Russ. Geol. and Geophys., v. 35, p. $5-23$.

Bogolepov, K. V., 1967, Mesozoic tectonics of Siberia: Moscow, Nauka Press, 328 p. (in Russian).

Burov, E. B., Kogan, M. G., Lyon-Caen, H., and Molnar, P., 1990, Gravity anomalies, deep structure, and dynamic processes beneath the Tien Shan: Earth Planet. Sci. Lett., v. 96, p. 367-383.

Burtman, V. S., 1964, The Talas-Fergana strike-slip fault: Trudy, Inst. Geol., Akad. Nauk SSSR, v. 104: Moscow, Nauka Press, 143 p. (in Russian). 1975, Structural geology of the Variscan Tien Shan, USSR: Amer. Jour. Sci., v. 272A, p. 157-186.

Burtman, V. S., Skobelev, S. F, and Molnar, P., 1995, Late Cenozoic slip on the Talas-Fergana right-lateral fault, Tien Shan, Central Asia: Geol. Soc. Amer. Bull.

Buslov, M. M., and Kazansky, A. Yu., 1996, Late Paleozoic-Mesozoic strike-slip faults of the Earth's crust of the Gornyy Altay: Geological and paleomagnetic implications: Doklady RAN, v. 347, p. 213-217 (in Russian).

Buslov, M. M., and Sintubein, M., 1995, Structural evolution of the Teletskoye zone, Altay-Sayan folded area: Russian Geol. and Geophys., v. 36, p. 81-87.

Buslov, M. M., Delvaux, D., Zykin, V. S., and Saphonova, I. Yu., 1996, Structural features of the Chuya depres- sion and its orogenic frame: Their implications in terms of geodynamics, in Continental rift basins: Brussels, Belgian Ministry of Science Policy FRFCIM "Tectorift," BICER, INTAS, p. 93-134.

Cobbold, P. R., and Davy, P., 1988, Indentation tectonics in nature and experiment. 2. Central Asia: Bull. Geol. Inst. Uppsala, N. S., v. 14, p. 143-162.

Cobbold, P. R., Sadybakasov, E., and Thomas, J. Ch., 1995, Cenozoic transgression and basin development, Kyrgyz Tien Shan, Central Asia, in Rource, F., ed., Geodynamic evolution of sedimentary basins: Paris, Editions Technique.

Coulon, C., Maluski, H., Bollinger, C., and Wang, S., 1986, Mesozoic and Cenozoic volcanic rocks from central and southern Tibet: ${ }^{40} \mathrm{Ar} /{ }^{39} \mathrm{Ar}$ dating, petrological characteristics, and geodynamical significance: Earth Planet. Sci. Lett., v. 79, p. 281-302.

Crowley, K. D., Cameron, M., and Schaefer, R. L., 1991, Experimental studies of annealing of etched fission tracks in fluorapatite: Geochim. et Cosmochim. Acta, v. 55, p. 1449-1465.

Davy, P., and Cobbold, P. R., 1988, Indentation tectonics in nature and experiment. 1. Experiments scaled for gravity: Bull. Geol. Inst. Uppsala, N. S., v. 14, p. 129-141.

Delvaux, D., Dobretsov, N., Berzin, N., San'kov, V., and Miroschnichenko, A., 1995a, To what extent are the Baikal rift system and the Cenozoic depression of Gorno-Altai (South-Siberia) related to the IndiaEurasia collision? [abs.], in Spence, D. A., Burg, J.-P., and Spencer-Cervato, C., eds., 10th HimalayaKarakorum-Tibet Workshop, abs. vol.: Zurich, Mitt. Geol. Inst. Eidgenössischen Tech. Hochschuhle Univ. Zurich, Neue Folge, Nr. 298.

Delvaux, D., Moeys, R., Stapel, G., Melnikov, A., and Ermikov, V., 1995b, Paleostress reconstruction and geodynamics of the Baikal region, Central Asia. Part I. Pre-rift evolution: Paleozoic and Mesozoic: Tectonophysics, v. 252, p. 61-101.

Delvaux, D., Theunissen, K., Van der Meyer, R., and Berzin, N. A., 1995c, Formation dynamics of the Gorno-Altay Chuya-Kurai depression: Paleostress, tectonic and climatic control: Russian Geol. and Geophys., v. 36, p. 31-5l.

Delvaux, D., Vysotsky, E. M., Klerkx, J., Kuzmin, A., Matton, C., Selegei, V. V., Theunissen, K., and Fernandez-Alonso, M., 1995d, Evidence for active tectonics in Lake Teletskoe (Gorny Altai): Russ. Geol. and Geophys., v. 36, p. 100-112.

Delvaux, D., Moeys, R., Stapel, G., Petit, C., Levi, K., Miroshnichenko, A., Ruzhich, V., and Sankov, V., in press, Paleostress reconstructions and geodynamics of the Baikal region, Central Asia. Part II: Cenozoic tectonic stress and fault kinematics: Tectonophysics. 
Xiao, X. Ch., and Li, T. D., 1995, Tectonic evolution and uplift of the Qinghai-Tibet Plateau: Episodes, v. 18, nos. 1-2, p. 31-35.

Xuebing, D., et al., 1990, New paleomagnetic results from Yadong-Golmud geoscience transect and a preliminary study of the model of terrane evolution in Qinghai-Tibet Plateau: Bull. CAGS, no. 21, p. 39-148.

Yanshin, A. L., ed., 1975, Mesozoic-Cenozoic tectonics and magmatism of Mongolia: Moscow, Nauka Press, $308 \mathrm{p}$.

Yaoxiu, Z., et al., 1990, The paleomagnetic study on the Tibetan Plateau and preliminary discussion on its tectonic evolution: Geol. Memoir, Min. Geol. Min. Res., China, ser. 7, no. 6, 186 p.

Yarmolyuk, V. V., Kovalenko, V. I., and Samoilov, V., 1991, Geotectonic position of Late Cenozoic volcanism of Central Asia: Geotektonika, no. 1, p. 69-83 (in Russian).

Yarmolyuk, V. V., Kovalenko, V. I., and Ivanov, V. G., 1995, Late Mesozoic-Cenozoic within-plate volcanic province in Central-Eastern Asia: Projection of a mantle hot field: Geotektonika, no. 5, p. 41-67 (in Russian).

Zhalkovskiy, N. D., Kuchai, O. A., and Muchnaya, V. I., 1995, Seismicity and some characteristics of the stress field state of the Earth's crust in Altai-Sayan area: Russ. Geol. and Geophys., v. 36, p. 16-25.

Zhang Qingung et al., 1992, On the present uplift speed of Qinghai-Tibet Plateau: Chinese Sci. Bull., v. 36, p. 285-288.

Zonenshain, L. P., Kuzmin, M. I., and Natapov, L. M., 1990, Geology of the USSR: A plate tectonic synthesis: Amer. Geophys. Union, Geodynamic monograph, v. 2l, 242 p.

Zonenshain, L. P., and Savostin, L. A., 1979, Introduction to geodynamics: Moscow, Nedra Press, 310 p. (in Russian).

1981, Geodynamics of the Baikal Rift Zone and plate tectonics of Asia: Tectonophysics, v. 76, p. $1-45$.

Zorin, Yu. A., Balk, T. V., Novosyolova, M. P., and Turutanov, E. Kh., 1988, Lithosphere thickness beneath the Mongolian-Siberian mountainous area and adjacent regions: Izv. AN SSSR, ser. fizika Zemli, no. 7, p. 32-42 (in Russian).

Zyat'kova, L. K., 1977, Structural geomorphology of the Altai-Sayan uplands: Novosibirsk, Nauka Press, 214 p. (in Russian).

Zykin, V. S., and Kazansky, A. Yu., 1995, Stratigraphy and paleomagnetism of Cenozoic (Pre-Quaternary) deposits of the Chuya depression in the Gornyy Altay: Russ. Geol. and Geophys., v. 36, p. 67-80. 